\title{
Arkitekten L. A. Winstrups vigtigste Arbejder.
}

\author{
Af + Erik Bondo Svane.
}

(Fortsat.)

\section{IV.}

\section{Frølichs Malerier.}

Som nævnt var Appellationsretten blevet udsmykket med to store Malerier af Lorenz Frølich; disse har en særlig dramatisk Historie, som er blevet udførligt skildret af Arkivar, cand. mag. Henny Glarbo i en Artikel i Tilskueren for 1930 pag. 210 o. følg. paa Grundlag af Frølichs Breve til Winstrup og Regenburg, af hvilke de fleste er gengivet in extenso eller $\mathbf{i}$ fyldige Uddrag. Brevene giver et herligt Billede af Frølich, som han var, den glade, muntre unge Mand, men samtidig den bevidst arbejdende Kunstner, der fuldt ud var klar over sine Evner og sit Kald; til denne Fremstilling henvises Læserne, og naar Sagen paany fremdrages paa dette Sted, sker det for nærmere at belyse Winstrups Andel i Begivenhederne samt for at tilføje enkelte supplerende Træk.

Samtidig med, at Winstrup havde besluttet at hæve Loftet i Appellationsretten for at give Plads til Tilhørergalleriet, havde han bestemt, at de store Syd- og Nordvægge skulde dekoreres med Malerier af stort Format (Højden 2,80 m, L.ængden 5,20 m). ${ }^{1}$ ) Paa sine Tegninger fra Marts og fra April 1852, betegnede henholdsvis som A 1 og A 5, havde han antydet, at det ene af Billederne skulde forestille Valdemar Sejr, der giver Jydske Lov, et Motiv, der var nærliggende for en Retsbygning, der bar Indskriften: „MED LOGH SCAL LAND BYGGES“. Paa Københavns gamle Raadhus, hvor Indskriften lyder: „MED LOV SKAL MAN LAND BYGGE“, havde man da ogsaa i 1838 tænkt sig Frontespicen udsmykket med en Gruppe af $\mathrm{H}$. V. Bissen, frem-

1) Die Heimat 1909 p. 34 . 
stillende samme Motiv. $\left.{ }^{2}\right)$ Men der var en særlig Grund til at vælge netop dette Motiv ved Sønderjyllands Højesteret, idet Valdemars Lovbog stadig var og lige indtil Aar 1900 vedblev at være Grundstammen 1 den slesvigske Civilret. Winstrups Udkast fra Marts er farvelagt, og paa den lille, smukt udførte Skitse ser man Kongen staaende paa en Tingsten, omgivet af sit Folk. Tanken om denne dekorative Udsmykning blev godt optaget i det slesvigske Ministerium, som det ses af en Underhaandsskrivelse fra Departementschef Kranold: $:^{3}$ ) „Hvad de ca. 40.000 Rdl. angaae, der ere bevilgede til Bygningens Istandsættelse, saa er i denne Sum indbefattet de 4000 Rdl., som ere anslaaede til de af Dem proponerede Malerier; brug dem endelig ikke til andre Ting".

I August 1852 vendte Frølich, der hidtil havde opholdt sig i Paris for sin Uddannelses Skyld, tilbage til København;') man kan formode, at han har lagt Vejen over Flensborg, og der har han naturligvis truffet Vennen Winstrup. Hvorom alting er, de to Venner har drøftet Muligheden af, at denne Opgave blev overdraget Frølich.

Den 4. Oktober 1852 skrev Winstrup om Sagen til Ministeriet: :Saafremt det høje Ministerium maatte billige, at dette Arbejde overdrages en af de yngre Kunstnere, turde jeg maaske tillade mig hertil at foreslaa den talentfulde Maler Lorenz Frølich, en Søn af Consulen ${ }^{5}$ ) af samme Savn, der efter et 6aarigt Ophold i Tyskland, Italien og Paris netop nu er vendt tilbage til Danmark. Saa snart jeg har modtaget Ministeriets Bestemmelse angaaende disse Malerier, skal jeg sætte mig i Forbindelse med vedkommende, for i Forbindelse med ham at tage de fornødne Forarbejder ....." Og næste Dag skrev han til Frølich et Brev, der viser, hvormeget dennes Tarv laa ham

2) F. Hendriksen og Francis Beckett: Københavns Raadhus, Kbh. 1908 p. 5 og 7. Den forskellige Formulering skyldes, at Indskriften i Flensborg gongiver en midddellalderrlig Tekist, meidlens Ordiene piala Kabenhavns Raadhus er taget fra den reviderede Tekst fra 1590.

s) Skr. 1-185 fra Kranold til W.

4) F. Hendriksen p. 241.

5) Consul Frølich var Malerens Onkel, ikke Fader. 
paa Sinde: „Min kjære Frølich. I Dag afsender jeg en Skrivelse til Ministeriet, hvori jeg har foreslaaet dig til Udførelsen af de omtalte Malerier; jeg er nysgerrig efter at vide, hvad Moltke vil sige. Garlieb er i København og vil opsøge dig; jeg har bedet ham tale med Justitsraad Kranold om Sagen og haaber det vil ikke hjælpe saa lidt. Kan din Onkel som Bekjendt af Moltke ikke bidrage til, at Hs. Exellence lettere gaar ind paa Forslaget? - jeg haaber det bedste ....... $\left.{ }^{6}\right)$

Det varede imidlertid ikke længe inden Ministeriet havde billiget Planen, thi allerede den 8 . Oktober paalagde det Winstrup at forhandle med Frølich „og forelægge Ministeriet Udkastene til Malerierne, hvilke Ministeriet dog, uden derved at indskrænke Kunstnerens Valgfrihed, formener passende kunde fremstille foruden som i Deres Indberetning af $7 / 4$ d. A. ) Kong Waldemar, som giver „Jydske Lov“, endvidere „Kong Frederik IV.'s Hyldning paa Gottorp Slot““. Det sidste Emne havde Carl Moltke selv foreslaaet; herved vilde man tilkendegive, at Sønderjylland siden 1721 havde hort under den danske Krone.

Efter Modtagelsen af Ministeriets Skrivelse meddelte Winstrup Sagens heldige Udfald til Frølich, der var lykkelig og straks svarede: „Jo større Svin, des bedre Lykke“, det kan jeg nok anvende paa mig selv, jeg havde ej smigret mig med Troen paa et lykkeligt Udfald, og mindst, at det skulde gaa saa raskt ...... Dig har jeg rigtignok at takke for denne Lykke, som man maa kalde for sjælden i dette Tidsrum, og som vel mange vil misunde mig; nu gjælder det om, at jeg godtgør din Tillid“. ${ }^{5}$ ) For at forstaa dette, maa det erindres, at Frølich mest havde opholdt sig i Udlandet og endnu ikke havde haft rigtig Lejlighed til for Alvor at vise, hvad han duede til som Maler; tilmed havde han forladt Akademiet under sin Uddannelse og følte sig - det være sig med Rette eller Urette $i$ et Modsætningsforhold til den almægtige Kunsthistoriker borg.

6) Gengivet i F. Hendriksen p. z44. Garlieb var Politimester i Flens-

7) Denne Indberetning ses ikke at eksistere.

8) Udateret Skriv. p. 211. 
Höyen og hans Kreds.') Det er derfor Winstrups uvisnelige Fortjeneste, at han havde $\varnothing$ je for Frølichs Talent og Mod til at betro ham disse store Opgaver og dermed skabe Mulighed for, at han fik udført sine Hovedværker indenfor Historiemalingens Omraade.

Det hedder videre i Brevet: „Min Plan i Vinter at arbejde i Paris bliver dog nok ved Magt, jeg haaber i Enden af næste Uge eller den derpaa følgende at komme til Flensborg. Jeg maa have Historiebogen med mig. Gud ved, hvordan vi bliver enige om Sujetterne; jeg vilde saa forbandet gjerne male et mytologisk og et historisk ........".

Allerede her er antydet Spiren til en Konflikt mellem Kunstneren og Bygherren. Frølich opfattede Opgaven som rent kunstnerisk og dekorativ, medens Ministeren først og fremmest betragtede den som politisk: Det skulde slaas fast klart og utvetydigt, at Sønderjylland civilretligt var dansk Retsomraade og statsretsligt hørte til den danske Krone.

I Slutningen af Oktober lagde Frolich atter Vejen over Flenshorg, hvor han opholdt sig et Par Dage, ,juleglad over Bestillingen ", ${ }^{10}$ ) for at drøfte det nærmere fornødne med Winstrup. Derefter drog han til Paris. Opgaven interesserede ham meget, og i Labet af Vinteren udarbejdede han to mythologiske Skitter: "Lokes Dom" og „Asernes Guldalder"; da det havde været Meningen, at Billederne skulde males direkte paa Væggen, onskede han ogsaa i Paris og Berlin at dygtiggøre sig i den særlige Teknik, som udkrævedes hertil.

Imidlertid var man i Ministeriet blevet utaalmodig over intet at høre om Sagen, og i Midten af April spurgte man Winstrup, hvordan det gik. ${ }^{11}$ ) Han svarede, at han havde meddelt Frelich Ministeriets Skrivelse af 8. Oktober 1852, men tilføjede: „Da Ministeriet $i$ det mindste til en vis Grad har overladt Kunstneren Valgfrihed, har denne ikke kunnet undlade at fremsætte

9) Se bl. a. F. Hendriksen p. 246, 380 og 390.

10) Skr. 2/11 1852 fra W. til Garlieb (Pakken: Almindelige Sager i Flensborg).

11) Skr. 14/4 1853 fra Sl. Min. til W. Skr. 18/4 1853. 
det Ønske ved Siden af ovenanførte Udkast af rent historisk Karakter at forsøge sig $\mathrm{i}$ anden Retning, der for vedkommende i kunstnerisk Henseende er mere tiltalende, nemlig at vælge Fremstillingen af Nordens Mythologi, hvorved Dekorationen vilde faa en mere symbolsk Betydning“. Brevet endte med, at Frølich i Slutningen af næste Maaned vilde komme hjem fra Paris."

Herpaa kom Svaret den 18. Maj 1853; naar det havde trukket saa længe ud, skønt Ministeriet for Slesvig ellers arbejdede meget hurtigt i sine Byggesager, skyldtes det vistnok, at Moltke havde været paa Rejse i Sønderjylland, hvor han i Flensborg havde truffet Winstrup og talt med ham om Frølich. „Han sender os dog vel noget inden han begynder at male?" havde Ministeren spurgt, og paa Winstrups bekræftende Svar havde han fortsat: „Ja, for det kan være meget godt i kunstnerisk Henseende, hvad Maleren kan onske at udføre, men vi andre maa dog ogsaa først vide, hvordan det ser ud i politisk Henseende“. Winstrup havde underrettet Frølich om det optrækkende Uvejr og havde paalagt ham til sin Tid, naar han indsendte Skitserne, at ledsage dem med Udkast af de oprindelige 2 Opgaver. Fr. IV. var ikke til at komme udenom, da det var Moltkes egen Opfindelse, „og han i det mindste kan være stædig. Jeg kan imidlertid godt indse, at det er to Gjenstande, der ikke passer godt til hinanden ..... Valdemar fra 1241 og Fr. IV med sine Parykker fra 1720 . Skulde man derfor ikke forsøge endnu en Opgave, f. Eks. Thyra, der bygger Danevirke, eller om du kan finde en anden Scene af Slesvigs Historie. Muligen at Hyldningen engang kunde blive anbragt i Stændersalen; der forekommer den mig at være bedre paa sin Plads end i Retssalen, dog det bliver ikke med det forste ". ${ }^{12}$ )

Frølich svarede 12/5 1853 fra Paris: „Moltkes Bemærkninger forandrer imidlertid intet $\mathrm{i}$ min Plan; han kan jo ej videre end forkaste den? ...... Skal det imidlertid være historiske

12) Skriv. fra W. til Fr. Hendriksen. 
Kompositioner, saa vilde jo foruden Valdemars Lov Thyras Vold, som du foreslaar, være en herlig Opgave ......"

Ved Ministeriets Skrivelse af 18. Maj 1853 brød Uvejret løs. Skrivelsen indeholdt en alvorlig Irettesættelse til Frølich og endda Trusel om at fratage ham Arbejdet. Det blev paalagt Winstrup at meddele Frølich, at Ministeriet ikke anser det for passende, at der $i$ en christelig Rets Forsamlingssal anbringes Fremstillinger af mythologisk Indhold, og at det derfor ikke kan give sit Samtykke til det af Kunstneren attraaede Valg. Med Hensyn iøvrigt til det lange Tidsrum, der er forløbet siden der om nærværende Sag blev indledet Underhandling med bemeldte Frølich, uden at det endnu er kommet til endeligt Resultat, udbedes Hr. Stadsbygmesterens Ytringer, om det maatte være hensigtsmæssigt at overdrage Udførelsen af Malerierne til en anden Kunstner eller muligvis rent at opgive dem ........"

Winstrup skyndte sig ved Skrivelse af 24. Maj at afværge Uvejret: han skrev, at man hverken burde overdrage Opgaven til en anden Kunstner, da han ikke vidste, hvem det skulde være, eller opgive Malerierne, da „Tilstedeværelsen af et Kunstværk vist ikke kan andet end virke gavnligt paa et Sted som Flensborg, der er aldeles blottet for Kunstgjenstande og hvor Interessen for samme er saa godt som ingen og vel kunde trænges til at vækkes. Den private gjør intet i saa Henseende, dertil er han for materiel“. Derefter forklarede han nærmere, hvorfor Fralich opholdt sig i Paris, og sluttede med at forsikre, ,at det hverken er Ladhed eller Ligegyldighed fra hans Side, som er Aarsag til, at Udkastene endnu ikke foreligger, men at han tværtimod med al Interesse og Flid har taget sig af Sagen“. løvrigt hastede det ikke, da Salen langt fra var færdig.

Forinden havde Winstrup underrettet Frølich om den Vending, Sagen havde taget. Det var et Tordenslag, der traf ham. Bl. a. svarede han, at hvis en anden Kunstner skulde udføre Arbejdet, burde det være (Holger ?) Roed. I denne Sammenhæng er det værd at bemærke, at de 3 Kunstnere senere kom til at samarbejde ved Ombygningen af Ødis Kirke, hvor Roed 


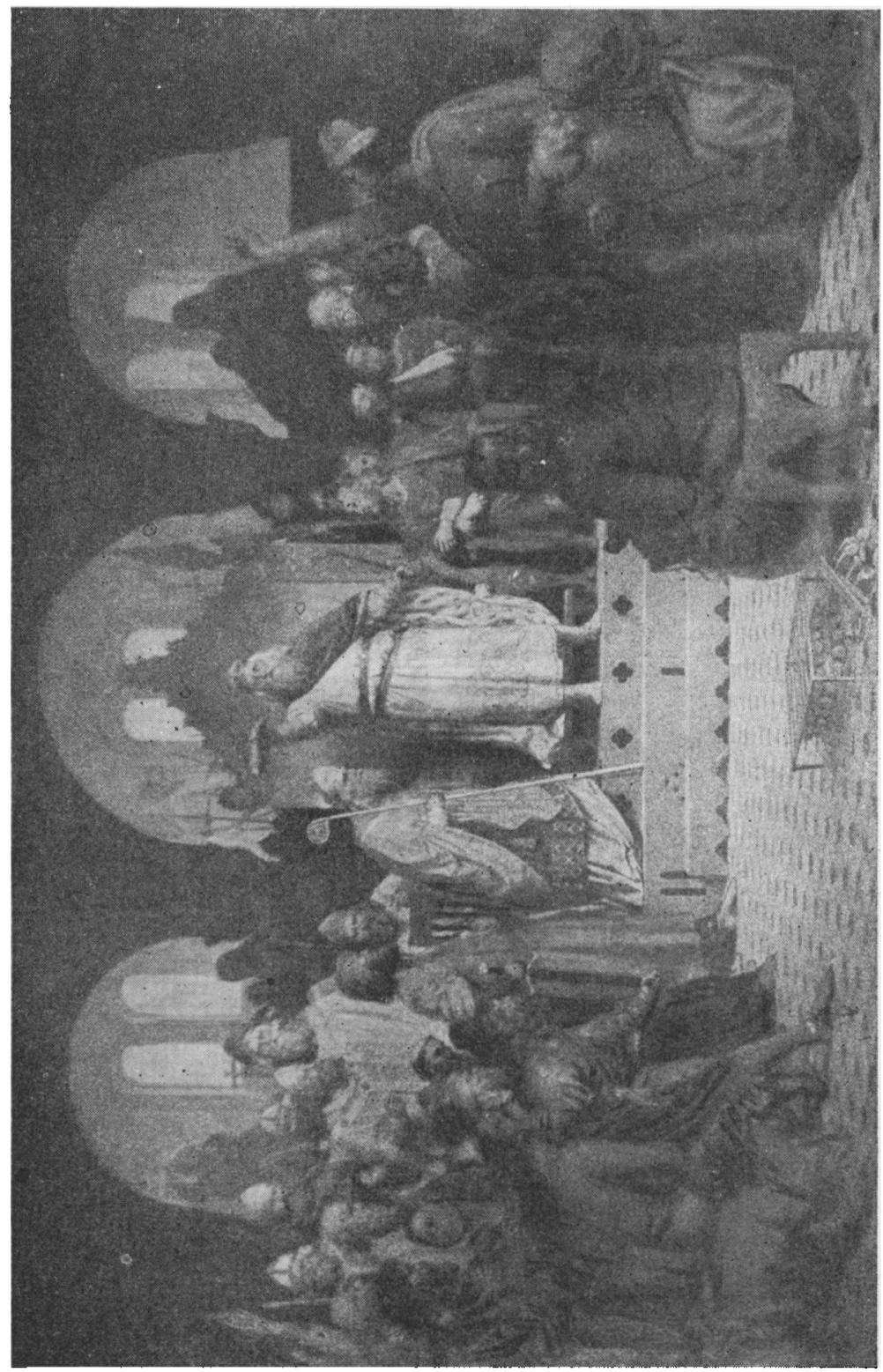


malede Altertavlen og Frølich udsmykkede Prædikestolen, men herom mere senere. Omsider maatte Frølich bekvemme sig til at udarbejde Skitsen med de to opgivne Emner. Den 11. Juli 1853 afsendte han 5 Skitser: Valdemar Sejr, Frederik IV, Thyra Danebod, Lokes Dom og Guldalderen til Winstrup, der lod dem udstille for deres fælles Venner paa Raadhuset, saadan som det ses af et Brev af 29/7 1853:13) „Baade jeg og de andre, som hidtil har set dem, synes godt om dem alle, dog saae vi jo helst de mythologiske Scener udførte; af de andre finder jeg Thyra paa Dannevirke fortræffelig; som Malerie vil det vist gjøre en herlig Virkning. Jeg har glædet mig over at see, hvad du har faaet ud af de to Opgaver Valdemar og Frederik IV; det er interessante Compositioner, som nok skulle gjøre deres Virkning. Om nogen Tid sender jeg dem til din Fader; jeg synes han burde se dem, inden de falder i Ministerklør, og da bede ham sende dem op i Ministeriet.“.

Da Frølich havde bebudet sin Ankomst i København, ventede Winstrup foreløbig med at fremsende Udkastene og nøjedes med under 21/7 1853 at meddele Ministeriet, at de var kommet. I København rasede imidlertid Choleraen, og Frølichs Ankomst trak som Følge heraf ud. Den 9. September sendte Winstrup derfor alle 5 Udkast af Sted. Om de mythologiske Skitser hedder det undskyldende i den ledsagende Skrivelse, „Skjønt Ministeriet i Skrivelse af $18 / 5 \mathrm{~d}$. A. har tilkjendegivet mig, at man ikke har fundet det passende at anvende mythologiske Fremstillinger, har jeg troet ikke at turde undlade at indsende disse med de øvrige, da de var udarbejdede forinden jeg modtog Ministeriets Skrivelse desangaaende“.

Kort efter kom Frølich paa Grund af Faderens Sygdom uventet til København. uden at have lagt Vejen over Flensborg, og benyttede da Lejligheden til at tale med Departementschef Kranold; han blev modtaget overordentligt venligt; der var hverken Tale om nogen anden Maler eller om at op-

13) F. Hendriksen p. 247. Afsnittet om Ødis K. ufuldendt. 


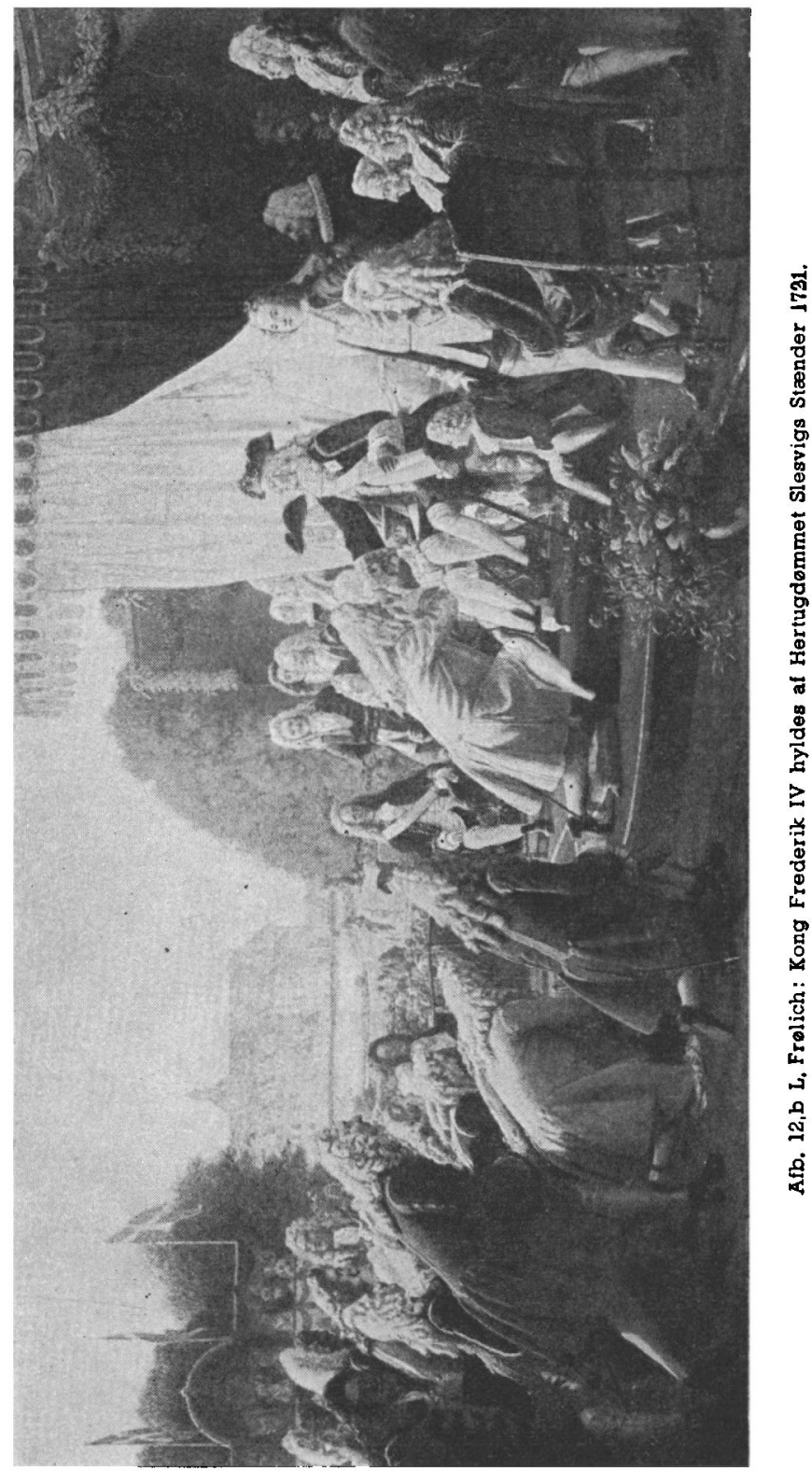


give Sagen, men heller ikke om andre end Ministerens to Opgaver; man ønskede dog et nyt Udkast til Hyldningsbilledet, da Frølich ikke havde haft tilstrækkeligt Kendskab om, hvad der virkelig var foregaaet 1721 og saaledes havde ladet de knælende Stænder overrække Frederik IV. den slesvigske Krone. ${ }^{4}$ ) Han maatte derfor ud til Professor Allen for at blive gjort bekendt med, hvad der var sket, og indsendte derpaa et ændret Udkast. Den 21/9 aflagde han Besøg hos Eksellencen Carl Moltke, der forklarede ham, hvorfor han maatte fastholde de to oprindelige foreslaaede Kompositioner, og det endte med, at Frølich maatte give ham Ret. Moltke var imidlertid ikke smaalig i historisk Henseende og havde saaledes intet imod, at Hyldningsscenen foregik $i$ det fri, skønt den vitterlig havde fundet Sted i en Sal paa Gottorp, og at Tordenskjold fremstilledes som værende til Stede, uagtet han var faldet omtrent et Aar forinden. ${ }^{15}$ ) I Oktober var Frolichs Skitser i Realiteten antagne, men den endelige Approbation trak ud paa Grund af en verserende Ministerkrise. ${ }^{16}$ ) Men omsider blev Winstrup under 23/2 1854 opfordret til at slutte Kontrakt med Frølich. Som Vederlag for at udføre de to Billeder „Valdemar Sejr udsteder Jyske Lov“ og "Frederik IV.'s Hyldning paa Gottorp" skulde han have 4000 Rdl. og Billederne skulde være færdige 1857 (Afb. $12 \mathrm{a}$ og b).

Frelich bosatte sig da i Flensborg. I November 1854 var Billedet af Valdemar Sejr færdigt. Under Udarbejdelsen af Hyldningsbilledet kom der paany Vanskeligheder, idet Regenburg, der var meget historisk interesseret, ikke kunde forlige sig med, at den afdøde Tordenskjold optraadte som Deltager ved Festen. Frølich forsvarede imidlertid sit Standpunkt med, at uagtet Tordenskjold „ikke var med og ikke kunde være med, saa burde han have været med; som den, der i Krigen havde arbejdet saa godt for at faa en god Fred, burde han være med ved dette

14) Skr. 19/9 1853 pag. 214.

15) Tordenskjold døde 20/11 1720, og Hyldningen paa Gottorp fandt Sted 4/9 1721.

16) Skr. 2/11 1853 fra Kranold til W. - Skr. $7 / 21854$ fra W. til Fr. Hendriksen p. 250. 
Resultat ....... endelig tror jeg, at de fleste ej skulde være stivere $i$ deres Historie, end at 1 Aar fra eller til ei skulde blive controlleret" ${ }^{17}$ ) Winstrup sluttede op bag Frølich, der under et Ophold i København havde talt med Conferensraad Christian Jürgensen Thomsen, Direktøren for Oldnordisk Museum, og denne havde ikke fundet noget stødende deri. ${ }^{18}$ )

Resultatet blev et Compromis, idet Frølich nøjedes med at antyde Ansigtstrækkene paa den kække unge Søofficer, der staar paa Tronens Fod "noget forandret vil han overlade Tilskueren at døbe, og skulde han beholde lidt Lighed med Tordenskjold, saa burde det jo være en mulig Tilfældighed"“. ${ }^{19}$ ) Hermed var den værste Anstødssten ryddet af Vejen; de andre historiske Unøjagtigheder var der ikke rejst Indvendinger imod, f. Eks. at Holberg og Hans Egede blcv fremstillet som værende til Stede, skønt de vitterligt havde henholdsvis siddet $\mathrm{i}$ København og været paa Vej til Grønland. For at forstaa dette, maa man gøre sig klart, at det Frølich tilsigtede, ikke var en saglig, historisk Skildring af Begivenheden i 1721, men en fri digterisk Fortolkning, der skulde staa som en Apotheose over Fr. IV og hans Mænd. Til Sammenligning tjener, at da Jørgen Sonne ca. 1/2 Snes Aar forinden malede sin berømte Frise paa Thorvaldsens Museum, tog han sig lignende Friheder, skønt den store Kunstners Hjemkomst var en Begivenhed, som var Folk paa ganske nært Hold; Fru Heiberg ses saaledes yndigt vuggende i en Baad paa Sundet, omgivet af Skuespillerinder, skønt hun selv fortæller i sine Erindringer, at hun opholdt sig i sin Have o. s. v. Men netop ved saadanne Friheder opnaaede Sonne at sætte Slægten omkring 1840 et Minde, værdigt og monumentalt, som kun faa Slægtled har sat sig. ${ }^{20}$ )

I November Maaned 1857 var Hyldningsbilledet færdigt. Som nævnt havde Frølich syntes bedst om de to mythologiske

17) Skr. 11/6 1856. Glarbo i Tilskueren 1930, p. 220.

18) Skr. 15/6 1856 fra W. til Regenburg. Regenburgs Arkiv.

19) Skr. 11/6 1856 pag. 220.

20) Se nærmere Sigurd Schultz: $\gg D a$ Thorvaldsen kom hjem«, Kbh. 1938 p. $47-56$. 
Skitser, og de havde ogsaa vakt stort Bifald hos Vennerne, men saa vidt det kan ses, er der ikke senere gjort noget Forsøg paa at bygge videre paa dette Grundlag. Derimod udsendte Kunstforeningen i Flensborg, som var blevet oprettet for at opelske Flensborgernes Kunstinteresse, i Aaret 1855 som Gave til sine Medlemmer den skønne Radering „Danevirke“, der bygger paa Frølichs indsendte Skitse „Thyra Danebod“, om end der er visse Afvigelser. Winstrup var Sjælen i Kunstforeningen, ligesom han ogsaa syslede med Planer om at faa oprettet et Kunstmuseum i Flensborg, og det var til ham, Rektor Povelsen henvendte sig, da han tænkte paa at lave en lignende Forening i Slesvig. At netop Winstrup maatte være ivrig for at faa dette Blad udsendt, er klart, da han havde syntes særdeles vel om denne Komposition, som han iovrigt selv havde givet Idéen til. Han opgav imidlertid ikke Haabet om at faa denne Tegning udført som Monumentalmaleri; i hvert Fald foreligger der to Udkast til Udsmykning af Festsalen paa Flensborg Latin- og Realskole, hvor Billedet var tænkt anbragt bag Talerstolen, dækkende den ene Endevæg. ${ }^{21}$ ) (Afb. 22). Men inden denne Plan var realiseret, var Krigen i 1864 brudt ud.

Krigen fik afgørende Følger for Frølichs Malerier; den oprindelige Plan at male dem direkte paa Væggene, havde man opgivet, og i Stedet for var de blevet malet paa Lærred, og var saaledes transportable. For alle Eventualiteters Skyld havde Ministeriet derfor ved Skrivelse af 2/2 1864 anmodet Winstrup om at foranstalte de i Regeringsbygningen anbragte to store Malerier nedtagne og forsvarligt indpakkede sendte enten til Als eller til København, alt efter Winstrups eget Valg. Winstrup valgte København; her var Malerierne sikret og kunde desuden udstilles paa Charlottenborg, thi "de fortjente dog at ses af andre end af den lille Kreds, for hvem de i Flensborg var tilgængelige“. Winstrup gav omgaaende efter Brevets Modta-

21) Denne Skitse findes i Pakken "Regeringsbygningen i Flensborg I i Lægget Frølichs Breve, den anden blandt Tegningerne til Latinskolen. Sagen behandles meget udførligt pag. 190. 
gelse Tømrermester i Flensborg C. G. Nielsen de fornødne Instruktioner, som øjeblikkelig blev efterkommet og Malerierne henstod herefter indpakkede paa Galleriet i Retssalen, da „den vist for alle uventede Opgivelse af Dannevirkes Forsvar" indtraf, og Omstændighederne selvfølgelig forbød at fjerne dem. Vel kunde Nielsen den 5/3 1864 skrive: „Frølichs Malerier staar meget godt, og det lader næsten til, at man har glemt dem, da det ikke er faldet nogen ind at spørge om dem." Winstrup saa dog mere alvorligt paa Situationen og ansaa Maleriernes Skæbne for tvivlsom, „hvis der ikke enten ad officiel eller privat Vej gjøres Skridt til at frelse dem".

Naturligvis kunde disse store Kasser ikke $\mathrm{i}$ det lange Løb staa upaaagtede, og Malerierne blev atter dragne frem. De blev nu prøjsisk Statseje, hvilket jo var en ganske simpel Følge af Souverænitetsoverdragelsen. Men i Regeringsbygningen hang ogsaa et tredie Billede af Frølich: „Kristi Fristelse“, malet i Flensborg vistnok til Brug for Husby Kirke i Angel og udstillet af Kunstforeningen, hvis Udstillinger som nævnt holdtes i Regeringsbygningen. ${ }^{22}$ ) Da Maleriet ikke var blevet solgt, havde det faaet Lov at blive hængende, medens Frølich selv 1857 rejste til Paris. Skønt Billedet saaledes retteligt var Frølich tilhørende, blev ogsaa det tilegnet af de nye Magthavere som erobret Statsejendom. ${ }^{23}$ )

Om Maleriernes videre Skæbne skal blot anføres, at Fr. IV er blevet ført til Regeringsbygningen i Slesvig og nu smykker Overpræsidentens Audienssal. ${ }^{24}$ ) De to andre findes paa Domhuset i Flensborg; „Valdemar Sejr“ i Amtsretssalen (Straffekammeret) og „Kristi Fristelse“ i Landsretssalen (Nævningesalen).. ${ }^{25}$ ) I 1909 var „Frederik IV.“ og „Kristi Fristelse“ udlaante til Frølichs Mindeudstilling i København og vakte der stor Opsigt som Arbejder af betydelig Værdi. I 1919 gjorde

22) Se p. 168 .

23) Architekten 1917-18 pag. 363.

24) Agnes Slott-Møller: Danske historiske Minder: Slesvig By, Slesvigsk Forlag 1926.

25) Die Heimat 1909 p. 275. 
Danmark officielt Skridt til Erhvervelse af de 3 Malerier: I det danske Memorandum til Fredskonferencen om Kunstgenstande, videnskabelige, litterære og historiske Aktstykker i Slesvig af 15/5 1919 hedder det i Afsnit VIII: „Det vilde være retfærdigt, om dette Billede (Frederik IV) blev tilbagegivet Byen Flensborg, hvis denne paany blev dansk. I modsat Fald synes det at være ret og billigt, at udlevere de tre Billeder til Danmark, som sandsynligvis til Gengæld vil kunne tilbyde Tyskerne Kunstværker af Interesse for dem. Skulde det ikke være Tilfældet, vil Billederne være at betale efter Vurdering." ${ }^{\text {(20) }}$

Memoiret er forfattet af $\mathrm{H}$. V. Clausen. Som bekendt kom der intet ud af Sagen.

\section{V.}

\section{Af Haderslev Latinskoles Forhistorie.}

Ligesom Winstrup af Ministeriet for Hertugdømmet Slesvig havde faaet overdraget Arbejderne ved Regeringsbygningen i Flensborg, betroede Ministeriet ham Opførelsen af Latinskolerne i Haderslev og Flensborg.

Efter 1797 havde der kun været 4 Latinskoler i Sønderjylland, nemlig i Slesvig, Husum, Flensborg og Haderslev.') De var alle tysksprogede, men efter 1814 gaves der dog Undervisning i Dansk, selv om denne var meget mangelfuld.') I Aaret 1850 og følgende Aar skete imidlertid store \#ndringer indenfor det lærde Skolevæsen.

Domskolen i Slesvig fortsatte med tysk Undervisningssprog, men fik nye Lærere, væsentlig Nord fra. 1851 havde den kun 27 Elever, men i 1863 var man oppe paa 135, hvilket svarer til de bedste Aar inden 1848. Den havde til Huse i det gamle Kapitelshus Syd for Domkirken, hvor nu det kommu-

26) Franz von Jessen: Haandbog i det slesvigske Spørgsmaals Historie II p. 267.

1) Sdj.s Historie III 468.

2) I Husum var Danskundervisiningen dog indfort et Par Aar forinden. 
nale Bygningsdirektorat (Bauamt) findes. Da Bygningen var meget gammeldags og blandt andet ganske manglede Solemnitetssal, ønskede Rektoren Søren Povelsen sig en ny Skolebygning og henvendte sig i 1859 til Winstrup angaaende en Plan om at flytte Skolen til det Scheelske Palais ved Lollfuss, der nu benyttes som Domhus. ${ }^{3}$ ) Men Winstrup fraraadede Planen og anbefalede i Stedet for at søge en passende Byggegrund; der kom imidlertid intet ud af Sagen. ${ }^{4}$ )

Latinskolen i Husum havde i 1840'erne haft ca. 50 Elever om Aaret og blev i 1852 nedlagt som Følge af den ringe Tilgang. I Stedet for oprettedes en højere Borgerskole, som imidlertid havde endnu vanskeligere ved at trives og i 1863 kun havde 19 Elever. ${ }^{5}$ ) Under saadanne Omstændigheder maatte man, saa godt man kunde, klare sig i det gamle Skolehus fra 1531.

Helt anderledes formede Udviklingen sig i $\mathrm{H}$ a d e r s le v. I 1840'erne havde Haderslev lærde Skole i Gennemsnit kun haft ca. 42 Elever, ${ }^{6}$ ) og da den den 7. Oktober 1850 genaabnede som dansk Latinskole, havde den endda kun 12 Disciple, fordelte paa 4 Klasser. ${ }^{7}$ ) Foreløbig maatte man nøjes med den gamle Skolebygning, der endnu ligger Nord for Domkirken og nu benyttes til Brandstation; den var oprindelig blevet opført af Hertug Hans d. Ældre i 1567, men havde lidt meget ved den voldsomme Brand under Kejserkrigen 1627, saa den maatte underkastes en gennemgribende Istandsættelse, hvis den da ikke blev fuldstændig genopbygget fra Grunden af. Oprindelig havde den kun haft een Etage, men i 1733-34 blev der bygget en Etage til; herefter indeholdt Bygningen 11 Værelser, og havde ikke blot huset selve Latinskolen, men ogsaa Bolig for Rektoren og visse af Lærerne - samt endog paa et vist Tids-

3) Skr. 12/3 1859 fra P. til W. - Se nærmere: Trap Slesvig, Kortet over Slesvig By samt Fritz Fuglsang: Schleswig, Berlin 1931 pag. 64; her kaldes Bygningen Heespenhof efter sin oprindelige Ejer.

4) Skr. 20/12 1859 fra W. til P.; Originalen opbevares i Regenburgs Privatarkiv som Bilag til et Brev fra 1860 fra Poveisen til Regenburg.

s) E. Maller i "Nordfriesland «; Husum 1929, p. 242 o. flg.

-) Skoleprogrammer 1840-47. Minimum var 31, Maximum 54.

7) Efterretninger om Haderslev lærde Skole $1850-51$ p. 13. 
punkt Borgerskolen. ${ }^{8}$ ) Dette var dog forlængst hørt op, og allerede i 1799 var Rektor flyttet ned i et Hus paa Nørregade, der var købt til Rektorbolig. Ved Nyordningen i 1850 opgav ogsaa Lærerne deres Boliger, men til Gengæld flyttede Pedellen, der hidtil havde boet ude i Byen, ind.")

Forholdene var langt fra gode. Rektorboligen var i en saadan Stand, at Rektor Thrige ikke vilde bo i den - bl. a. manglede der saa godt som aldeles Have - og i Stedet foretrak han at flytte ind $i$ en lejet Lejlighed. Den tidligere Rektorbolig blev derpaa solgt.. ${ }^{10}$ ) I selve Skolen var IJlasseværelserne kun smaa og daarligt oplyste; med Undtagelse af et laa de alle paa øverste Etage med Udsigt ind i Genboens Stuer paa den anden Side af et smalt Stræde. Gymnastiksal fandtes ikke, saa man maatte benytte det største Klasseværelse, der imidlertid kun kunde rumme faa og ringe Apparater, hvorfor Undervisningen blev ensformig og kedelig. Da Skolen ganske savnede Legeplads, var Eleverne i Frikvartererne henviste til enten at opholde sig paa Kirkepladsen, der var almindelig Passage, eller i Klasseværelserne. Endelig generedes Undervisningen af Støj fra Gaderne og fra Pladsen. ${ }^{11}$ )

Rektor Thrige, der hidtil havde virket ved den moderne Roskilde Kathedralskole, var utilfreds med det gamle og uhensigtsmæssige Skolehus og skrev den 5. Maj 1851 til Regenburg: "Gid vi snart kunde faa en ny Bygning med Tilbehør! Endnu kan det vel ikke nytte at tale herom. Vil Ophævelsen af Husumerskolen ikke kunne hjælpe paa Finantzerne“. Men Regenburg kunde foreløbig ikke stille noget som helst i Udsigt. ${ }^{12}$ )

Det nye Skoleaar i 1851 aabnede med 37 Elever, fordelte paa 6 Klasser. ${ }^{13}$ ) Da der snart efter tilbød sig Lejlighed til at er-

8) Indbydelsesskrift $1850-51$ p. 23. - Indbydelsesskrift til Indvielsen af Haderslev lærde Skoles nye Bygning. - Haderslev 1854 p. 42.

9) Skr. 29/9 1850 fra Rektor til Min. Efterretninger 1850-52 p. 27.

10) Skr. 29/9 1850 fra Rektor til Regeringscommissæren.

11) Skr. 12/6 1852 fra Rektor til Slesv. Min. - Gymnastikværelset blev endda i Aaret 1852-53 inddraget som Klasseværelse.

12) Skr. 18/5 1851 fra Regenburg til Rektor.

13) Skr. 21/8 1851 fra Rektor til Sl. Min. 
hverve en passende Grund mellem Gaaskærsgade og Posthuset, 270 Alen lang og 200 Alen bred, hvoraf Ejeren, en Snedker Jørgensen, ønskede at afhænde en Del til Skolen, bragte Rektor Thrige paany Byggesagen frem: thi: „at Slesvigs eneste danske lærde Skole snart maa have et andet Lokale end det nuværende, kan der vel ikke være Tvivl om". ${ }^{14}$ )

Sagen blev straks sendt til Erklæring i Konservatoriet, der vel var stemt for Planen, men paapegede, at man maatte have et Overslag over, hvad en ny Skolebygnings Opførelse paa den paatænkte Byggegrund vilde koste, og at der, forinden et saadant Overslag forelaa, ikke vilde kunne tages Bestemmelse om, hvorledes Pengemidlerne kunde tilvejebringes. „Her paa Stedet", hedder det videre „kjende vi ingen, af hvem en Byggeplan med Tegning kunde udarbejdes, og vi tillader os derfor at indstille, at det høie Ministerium .... maatte behage snarest muligt at hidsende en Architekt, som kunde tage Localiteterne i Øjesyn og udkaste den fornødne Plan med Tegning og Overslag over den nye Skolebygning. ${ }^{15}$ )

Da Regeringen imidlertid ikke havde Penge til at bygge for, indskrænkede man sig foreløbig til at sikre en passende Byggegrund, ${ }^{16}$ ) herunder kom ogsaa andre Grunde paa Tale, og efter at der var indhentet forskellige Erklæringer, tilsidst ogsaa af Rektor, synes Sagen i nogen Tid at være stillet i Bero til stor Fortvivlelse for Rektor Thrige. ${ }^{17}$ ) Forgæves mindede han Regenburg om "vor Skoles Forhaabninger" og paany paapegede, at "den eneste danske Latinskole i Slesvig bør dog have det lidt anstændigt". ${ }^{18}$ )

Den 12. Juni 1852 henvendte Rektor Thrige sig paany officielt til Ministeriet og androg om, at det snarest muligt maa blive overdraget en dygtig Arkitekt at undersøge Pladserne og gjøre et Overslag over en ny Bygnings Opførelse, idet han nær-

14) Skr. 24/9 1851 fra Rektor til Slesv. Min.

15) Skr. 24/10 51 fra Conservatoriet til Sl. Min.

16) Skr. 11/11 51 fra Sl. Min. til Conservatoriet.

17) Skr. 14/1 52 fra Rektor til Sl. Min. - Indbydelsesskrift p. 42.

18) Skr. $12 / 51852$ fra Rektor til Regenburg. 
mere anførte Manglerne ved Bygningen og Vanskelighederne ved det stadig voksende Elevtal. „Hvert Aar voxer Elevantallet og hvert Aar bliver det nuværende Locale mere ubrugeligt. I Kongeriget har man forkastet langt bedre Bygninger og i Slesvig selv have de 2 andre Skoler langt bedre Lokaler. Vi, den eneste danske Skole, bur dog vel ikke staa tilbage. En anden Sag var det jo, da Skolen her var tysk og formedelst sin Unaturlighed ikke kunde blomstre. - - - Jeg maa derfor indstændigt andrage paa, at det høie Ministerium vil tage denne Sag under Overvejelse“.

Denne Gang havde Rektor Heldet med sig, thi den 29. Juli 1852 opfordrede Ministeriet Winstrup til at give Møde i Haderslev for sammen med Conservatoriet, Magistraten og Rektor at besigtige brugelige Byggegrunde og give Overslag over Opførelsen af en ny Skole samt vurdere den gamle Bygning, som man agtede at sælge.

Først den 20. August fandt Mødet Sted. Der var 3 Grunde, som kunde komme i Betragtning, nemlig foruden Snedkermester Jørgensens en Mark, som hørte til Amtmandsembedet og har ligget i Nærheden af Amtshuset, og en større Grund, der vistnok laa øst for Byen og tilhørte Kommunen; det havde været paa Tale, at.Kommunen vilde tilbyde den hele, hvorved man vilde faa lige saa meget Rum til Legeplads, Have og maaske Mark, det skulde være, men hele Gammel Haderslev, hvor mange af Disciplene boede, vilde faa en meget lang Vej at gaa, hvis Skolen blev opført her. Amtmandens Mark laa allermest afsides og endda uden for Bygrænsen, hvorfor Kommunen, hvis Skolen blev opført her, vilde unddrage den alle Bidrag. Den Jørgensenske Grund havde derimod den bedste Beliggenhed, thi med Undtagelse af Naffet, hvor der vel aldrig vilde komme til at bo mange Elever, havde ingen Del af Byen nogen lang Vej til den. ${ }^{19}$ ) Resultatet blev, at Komitéen indstillede, at man købte den af Rektor foreslaaede Grund i Gaaskærgade. Indstil-

19) Om de forskellige Grunde, se Skr. 14/1 52 fra Rektor til Min. 
lingen blev taget til Følge og den 15. Sept. 1852 sluttede Amtmanden en foreløbig Kontrakt med Snedker Jørgensen om Køb af et Grundstykke, 66 Alen bredt og 100 Alen dybt; øst herfor skulde anlægges en Gade og mod Vest opføres Beboelseshuse, hvori Lærerne kunde faa Lejligheder, saaledes at Skolen trods Grundens forholdsvis ringe Bredde vilde faa en fri Beliggenhed. Imidlertid havde man solgt Grunden for smal. „Efter at Rector havde opgivet alt, hvad der skulde skaffes Plads til i Skolebygningen, viste det sig, at man ikke kunde nøjes med mindre end 60 Alens Længde eller kun 6 Alen kortere end den valgte Grund er bred", saaledes at man kun kunde faa én Indkørsel af 4 Alens Bredde Vest for Skolen og mod Øst maatte lade sig nøje med en 2 Alen bred Gang. Da det tilmed hed sig, at den projekterede Tværgade Øst for Skolen vilde bortfalde, ansaa man det for absolut nødvendigt, at der blev købt mere Jord til, saa Bygningen kunde faa en Indkørsel paa 4 Alen ved hver Ende. Kravet blev ogsaa efterkommet, og der blev skrevet Skøde paa hele Grunden.

Men hvorfor valgte man ved Besigtigelsen den kun 66 Alens Bredde? Forklaringen maa sikkert søges i, at man den. gang mente, at Skolen vilde blive kortere end 60 Alen. Hvis man tænker sig, at den 66 Alen brede Grund maa afgive 6 Alen til Indkørseler, bliver der kun 58 Alen til selve Skolebygningen og to Alen til Gang, eller muligt $2 \times 4$ Alen til Indkørseler. Det er rigtigt, som Winstrup har anfort, at det var ,jo saa aldeles $i$ Blinde, at Størrelsen blev bestemt, da Tegningen dengang ikke existerede", men man havde dog Forbilleder at se hen til i de mange smukke Latinskoler, der var blevet rejst i adskillige af Landets Provinsbyer i Løbet af det 19. Aarh.s 1. Halvdel. Winstrup nævner selv Skolerne i Roskilde, Odense og Aarhus, idet han tilføjer: „kun disse kender jeg“. Henvisningen til Roskilde Katedralskole er interessant, thi det var jo fra den, Rektor Thrige kom, og den var netop 58 Alen lang. Det kan altsaa tænkes, at man ved Udstykningen af Grunden netop har haft Roskildeskolen i Tankerne. 
Blandt Tegningerne til Flensborg Latin- og Realskole findes enkelte til selve det endelige Projekt til Haderslev lærde Skole, samt to Planer, der benævnes „ukendt Skole“, og som er usignerede og udaterede. Vel har Facaden stor Lighed med et af Winstrups Projekter til Latinskolen i Flensborg, men Indretningen er en anden og peger snarere hen paa Haderslev, og da Tegningerne ligger sammen med Planer vedrørende Haderslev Skolen, kan man vistnok antage, at det drejer sig om Forarbejder til Haderslev lærde Skole.

Men saa bliver Forbindelsen med Roskilde Katedralskole ogsaa tydelig og klar. Katedralskolen her var i 1842 blevet forsynet med en ny Hovedbygning efter Tegning af Hofbygmester Kock. Den var en langstrakt toetages Bygning, Murene staar graapudsede, Taget, der er afvalmet, er af sort Tegl. Frem for Facaden springer ved hver Ende en Risalit; Indgangen findes paa Midten i det tilbagetrukne Midterparti og markeres af en Arkitrav, prydet med Kongens Navnetræk. Dør og Vinduer er rundbuede, Taget saavel som Tagene paa Risalitterne er afvalmede.

Den ene af Tegningerne til "den ukendte Skolebygning“ viser denne som 58 Alen lang og giver kun en Variation af Roskildeskolens Facadeskema. Dog er Enderisalitterne forsynet med gotiske Trappegavle, ligesom Taget er langt større som Følge af Bygningens større Dybde. Er der en vis Lighed mellem de to Skoler i Facadebehandlingen, hører Ligheden ganske op, naar man ser paa Indretningen. I Roskilde havde man særlige Bygninger til Rektorbolig og Gymnastiksal, medens den ukendte Skole har Rektorbolig og Skolelokaler samlede under samme Tag. I Hovedbygningen er Klasseværelserne lagt paa hver Side af en Korridor, modsat de ældre Latinskolers normalt benyttede System med Sidekorridor.

Begge disse Træk genfindes i Haderslev Skole, som den endelig blev.

Hovedforskellen mellem Planen for den 58 Alen lange Skole og det endelige Projekt er, at den første var tænkt som tre- 
fløjet, og at Midterkorridoren ikke er ført ud til Gavlene, hvorved Ordningen blev mindre klar og overskuelig.

Men der findes ogsaa en anden Plan for „den ukendte Skole“, hvorefter denne er gjort 2 Alen længere - altsaa med en Facadelængde paa 60 Alen. (Dette Afsnit ufuldendt).

VI.

Flensborg Latin- og Realskole.

Aarsagen til Haderslev-Skolens Vækst havde været Indførelsen af det danske Undervisningssprog; et saa radikalt Skridt vovede man ikke at foretage i Flensborg, men valgte i Stedet at gøre Undervisningen tvesproget, saaledes at der i visse Fag undervistes paa Dansk, i andre paa Tysk, dog at Sproget i Religionstimerne blev valgfrit. Samtidig blev Skolen udvidet med Realklasser og Forberedelsesklasser.')

Den nye Ordning medførte, at Skolen voksede stærkt, som nedenstaaende Tabel vil vise:

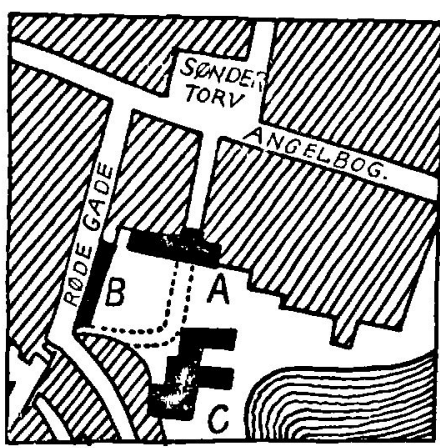

Afb. 12c. Skitseplan af en Del at Flensborg. A. Latinskolen. B. Fattighuset. C. Graabrødeklosteret.

\begin{tabular}{llrc} 
Sept. & $1852:$ & 73 & Elever \\
Nytaar & $1853:$ & 85 & $"$ \\
Juli & $1853:$ & 118 & $"$ \\
$"$ & $1854:$ & 183 & $"$ \\
$"$ & $1855:$ & 218 & $"$ \\
$"$ & $1856:$ & 245 & $"$ \\
\cline { 1 - 2 } Juli & $1863:$ & 338 &
\end{tabular}

Medens man i Haderslev valgte at bygge en ny Skole, nøjedes man i Flensborg med at ombygge og udvide den gamle Bygning, der stammede fra Aaret 1806; det var en 81 Alen lang

1) Se nærmere Indbydelsesskrift til den offentlige Examen i Flensborg Lærde- og Realskole 1852 pag. 260 fl. og Hjelholt pag. 172 o. flg. 
toetages Bygning, der laa $\mathrm{i}$ den sydlige Del af Byen Nord for det gamle Graabrødre Kloster..) Den var placeret i øst-vestlig Retning, tværs over den saakaldte Klostergang, som fra Søndertorv førte ned til Klostret. Kom man fra Torvet gaaende ned ad Gangen, vilde man møde et taarnagtigt Fremspring, lige saa bredt som Strædet og foroven afsluttet af en Trekantgavl; det var det eneste i Nordfacaden, der var synligt, Resten

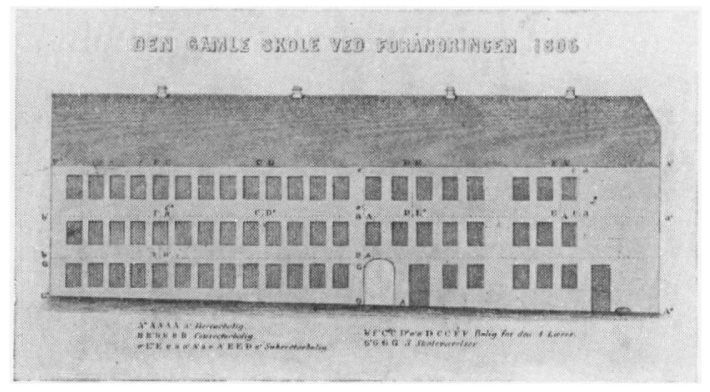

Afb. 13. Skolen 1806. Sydfacade.

var dækket af Haver og Baggaarde. Strædet fortsatte videre gennem "Taarnet". Her i Portgennemkørselen fandtes ogsaa Indgangen til Skolen, hvilket ofte kunde være uheldigt, da der mange Gange kom kørende saa store Fragt- og Torvevogne, at de $\mathrm{i}$ timevis blev siddende fast uden hverken at kunne komme frem eller tilbage. $\left.{ }^{3}\right)$ Fortsatte man gennem Porten og vendte sig om, vilde man se den lange og kedelige Sydfacade (Afb. 13), der med sine mange tætsiddende Vinduer mest af alt ledte Tanken hen paa en Lejekaserne, hvad Bygningen for saa vidt ogsaa var, som der kun var 6 Klasseværelser, et Forsamlingsværelse for Lærerne og et lidet Kammer for den physiske Samling, $\left.{ }^{4}\right)$ medens Resten næsten udelukkende var indrettet til $\mathrm{Be}-$ boelse for Rektor og Lærerne, saaledes at Rektorboligen indtog det meste af hele Partiet Øst for Porten.

2) Indbydelsesskrift til den højtidelige Indvielse af Flensborg Latinog Realskole -Flsb. 1861 p. VII.

3) Skoleprogram 1845 pag. 38.

4) Skriv. 23/851 fra Rektor Simesen til Slesv. Min. Rektor har glemt at omtale Bibiloteket. (Skolearkivet). 
De to karakteristiske Træk, "Taarnet“ og Gennemkørselen, var en Arv fra den tidligere Skolebygning, som blev nedbrudt i 1806, og hvis Kærne stammede fra en Stiftelse, som den forhenværende Franciskanermunk Lüdtke Namensen havde ladet opføre i Aarene 1553-57 og senere skænket til Skolebrug. ${ }^{5}$ )

Syd for Skolen laa Klosterkirkegaarden, der mod Vest grænsede til Fattighuset i Rødegade (Afb. 12c).

Den nye Skoleordning havde medført, at Klassernes Antal var vokset til 8; man inddrog derfor en af Lærernes Lejligheder, og i den følgende Tid, efterhaanden som Skolen voksede, blev den ene Lejlighed efter den anden inddraget, saa tilsidst kun Rektorboligen var tilbage, og Rektor Simesen havde endda afgivet et Par Værelser af denne. Men paa den anden Side var den berømte Jaspersenske Oldsagssamling, som Regeringen havde købt for $1000 \mathrm{Rdl}$. af Justitsraad Jaspersens Enke, blevet installeret i den i Forvejen trange Skole.") Skolen manglede ganske Gymnastiksal, hvorfor Undervisningen i dette Fag maatte foregaa i et Ridehus uden for Byen og Solemnitetssalen var blot et almindeligt Klasseværelse, som ikke var stort nok til at kunne rumme alle Eleverne.')

Rektor Simesen havde derfor ladet Winstrup udarbejde en Plan til en Tilbygning, indeholdende Gymnastik- og Solemnitetssal. Den 17/12 1852 blev Planen indsendt til Ministeriet. ${ }^{8}$ ) Der viste sig imidlertid Vanskeligheder, da Pengene skulde skaffes til Veje, idet Flensborg By intet kunde bidrage, $\left.{ }^{9}\right)$ men ved kgl. Resolution af $3 / 31854 \mathrm{blev}$ de fornødne Midler, 6000 Rdl., bevilget, hvorefter Bygningen blev opført. ${ }^{10}$ ) Det var en kort Tværfløj ved den vestlige Ende af Skolen. Saavel i det Ydre som det Indre adskilte den sig fra Hovedfløjen. Til den

s) Indbydelsesskrift p. VI.

6) Afskr. af Skriv. af 27/2 1852 fra Slesv. Min. til Rektor Simesen. Flensborg Latin- og Realskoles Arkiv, Rigsarkivet.

7) Koncept til Skrivelse 17/12 52 fra Simesen til Sl. Min. (Skolearkivet).

8) Koncept til Skrivelse 17/12 1852 fra Simesen til Slesv. Min. Flensborg Latin- og Realskoles Arkiv. Rigsarkivet.

9) Afskr. af Skr. 17/2 1853 fra Slesv. Min. til Simesen. (Skolearkivet).

10) Afskrift i Skolearkivet; se ogsaa Skoleprogram 1854 p. 38. 
noget nøgterne Sydfacade havde Winstrup nemlig knyttet en gotisk Trappegavl, og Fløjen var i Modsætning til den gamle Skole kun i to Etager, nederst Gymnastik- og ovenover Solemnitetssalen. I Hjørnet mellem de 2 Fløje var en Portal og bag denne en ny Hovedtrappe. ${ }^{11}$ ) (Afb.14). Tværfløjen fik altsaa sam

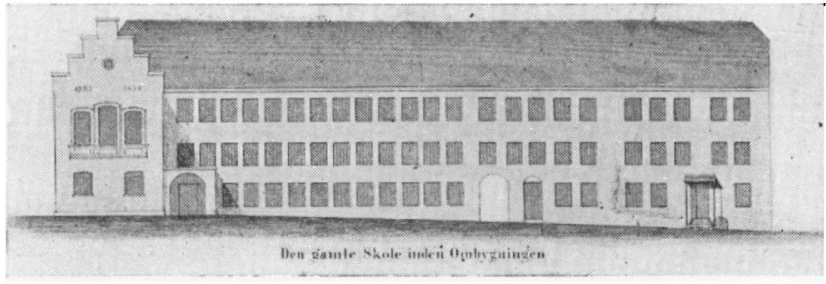

Afb. 14 Skolen inden Ombygningen i 1850'erne.

me Funktion som Sidefløjen paa Haderslev lærde Skole, hvilket kun er naturligt, da Planerne er udarbejdet omtrent samtidigt, nemlig i Efteraaret 1852. Skolens fortsatte Vækst vilde dog snart bevirke, at den maatte sprænge sine udvidede Rammer. Rektor Simesen bad derfor den 25/7 1854 Ministeriet om Tilladelse til at indkomme med Forslag om Skolebygningens Udvidelse, enten ved en Tilbygning eller en Paabygning af en Etage. Tilladelsen blev givet, og den 30/11 1854 indsendte Simesen en af Winstrup udarbejdet Plan. ${ }^{12}$ ) Tanken om at paabygge en Etage var nu skrinlagt, da Murene ikke kunde bære, og der knyttede sig ogsaa andre Ulemper til Planen; i denne Sammenhæng vil vor Tid med dens ivrige Dyrkelse af Lys og Sol sikkert forbavses, naar Rektoren som en Mangel anfører, at man „vilde faa for stor Solvarme om Sommeren, da alle Vinduer vender mod Syd“. ${ }^{13}$ ) Winstrups Plan gik ud paa, at der $\mathbf{i}$ Rektors Have - altsaa Øst for Klostergangen — skulde bygges en Sidefløj, vinkelret paa den gamle Skolebygning, som skulde fikses op. ${ }^{14}$ ) Paa Taget mod Syd ovenover Klosterporten tænkte

11) Indbydelsesskrift $p . X$.

12) Konc. i Skolearkivet. Afskr. af Skriv. 24/8 1854 fra Slesv. Min. til Simesen. Skolearkivet.

18) Konc. i Skolearkivet.

14) Skr. 28/11 1854 fra W. til Simesen. Slesv. Min. Arkiv. 
han sig anbragt et Observatorium, der skulde staa i Forbindelse med en Platform, som paa denne Maade vilde afslutte „Taarnet" paa den nordlige Side af Porten. For Enden af den nye Fløj skulde opføres et ottekantet Trappetaarn. ${ }^{15}$ )

Winstrup endte sin Indberetning med at gøre opmærksom paa Ulemperne ved Projektet, dels de gamle Klasseværelsers ringe $\mathrm{Højde}$, og dels, at hele Bygningen vilde faa en temmelig stor Udstrækning, og i et privat Brev til Regenburg fraraadede han hele Planen. Det har derfor sikkert været med Tilfredshed, at han erfarede, at Ministeriet under 9. December 1854 havde forkastet Projektet, idet man var mere stemt for en helt ny Bygning, hvis en passende Grund kunde findes. Ministeriet lod derfor samtidig nedsætte en Komité, bestaaende af Rektor Simesen og Winstrup samt et Medlem, udpeget af Magistraten, for „at tage Sagen om Opførelse af en ny Skolebygning og navnlig Spørgsmaalet om Udfindelsen af en passende Byggeplads under Overvejelse" ${ }^{16}$ )

Det viste sig imidlertid vanskeligt at finde en ledig Grund; til den Christiansenske Gaard, som Kommunen havde købt, hørte en stor Have, men Kommunen, der havde foretaget Erhvervelsen i „andet Øjemed“, vilde ikke afstaa Ejendommen. ${ }^{17}$ ) En Grund af Øvelgønnelykken oppe paa Bakkerne, hvor bl. a. det nuværende Gymnasium er beliggende -, „hvis frie og smukke Beliggenhed for øvrigt talte for der at henlægge en ny smuk offentlig Bygning“, blev forkastet, fordi den laa for isoleret og Tilgangen, navnlig om Vinteren, var meget besværlig. ${ }^{18}$ ) En anden Grund paa Munketoften, d. v. s. Syd for Byen, laa for ucentralt. ${ }^{19}$ ) Man valgte derfor at blive, hvor man var, og at opføre det nye Skolehus umiddelbart i Nærheden af det

15) Tegningerne til dette Projekt synes ikke at eksistere. En Tegning, sign. Jan. 1864, viser en Omdannelse af »Taarnet«, i Hovedtræk svarende til Planen af 28/11 1864 .

16) Afskr. 9/12 1854 .

17) Se Sdj. Aarbøger p. 214 (R. Baumanns Erindringer). Afskr. af Skriv. 26/4 1855 fra Mag. til Slesv. Minist. (Skolearkivet).

18) Konc. 11/5 1865 fra Simesen til Slesv. Min. (Skolearkivet).

19) Konc. til Skr. 6/2 1855 fra W. til Simesen. W.'s Arkiv. 
gamle, dels paa Klosterkirkegaarden, som ikke havde været benyttet siden 1811, dels paa Fattighusets Grund ud mod Rødegade, idet Fattighuset simpelt hen blev brudt ned og flyttet ud til Munketoften i en ny Bygning, som skulde opføres efter Winstrups Tegning.

I Januar 1856 udarbejdede Winstrup sine Planer, som Rektor Simesen derefter indsendte til Slesvigsk Ministerium. ${ }^{20}$ ) I Hovedtræk svarer de til den endelige Udførelse, men ikke i Enkeltheder. Winstrup betragtede det ogsaa selv ,som et foreløbigt Udkast, der trænger til at gennemarbejdes betydeligt, inden det kan kaldes færdigt, om det ogsaa, som det foreligger, giver en nogenlunde klar Oversigt over det hele Anlæg “. ${ }^{21}$ ) Den gamle Skole skulde efter en radikal Ombygning tjene til Gymnastik- og Solemniteissal, tillige til Museumsiokaler, samt huse en enkelt Lærerbolig, medens det nye Skolehus, en Vinkelbygning, bestaaende af en Syd- og Vestfløj med et svært Observationstaarn i Hjørnet, skulde indeholde de egentlige Undervisningslokaler, Rektorboligen samt Bibliotek og den fysiske Samling. De to Skolehuse skulde forbindes med en Buegang og vilde tilsammen danne et større trefløjet Anlæg, som omsluttede en Skolegaard.

Ved Skrivelse af 10/5 1856 sendte Ministeriet Tegningerne tilbage til Rektor Simesen og bad ham „opfordre Stadsbygmester Winstrup til at revidere samme ". ${ }^{27}$ ) Samtidig havde Regenburg $\mathrm{i}$ en Underhaandsskrivelse gjort Winstrup bekendt med, hvilke Findringer han onskede gennemført. ${ }^{23}$ ) Hjørnetaarnet burde bortfalde og Observatoriet anbringes i Midten af Bygningen, om det da ikke helt burde opgives. Ved at forlænge Fløjen mod Rødegade ud over det paatænkte Taarns Plads vilde Rektorboligen kunne gøres større, ligesom der kunde anbringes Klasseværelser som Reserve ved yderligere Udvidelse af Sko-

20) Afskr. af Skr. 12/2 1856 fra Simesen til Slesv. Min.

21) Skr. Febr. 1856 fra W. til Regenburg. Regenburgs Arkiv.

22) Afskr. i Skolens Arkiv.

23) Skr. 8/5 1856 Winstrups Arkiv. 
len. Mest interessant er det dog, at Regenburg ikke ønskede Biblioteket placeret oppe paa 1 . Sal i det nye Skolehus, men paa en saadan Maade, at der var nem Adgang dertil ogsaa for
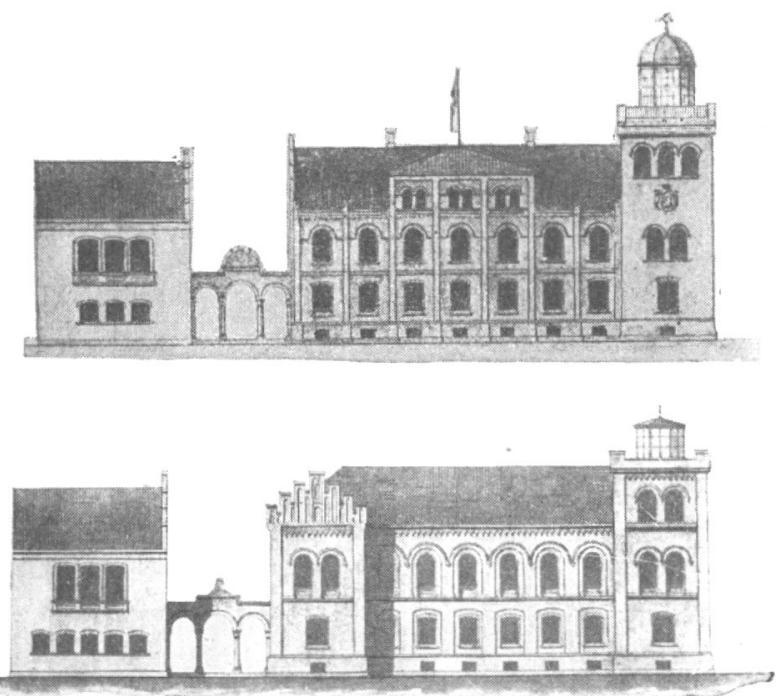

Afb. 15, a og b. Winstrups Udkast til Vestfløjen 1856 set fra Redegade.
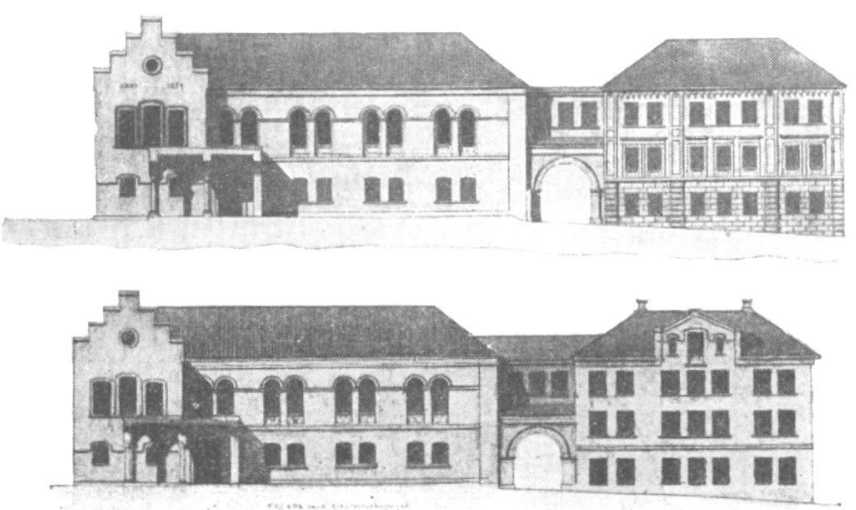

Afb. 16 a og b. Winstrufs Udkast til Nordflajen 1856 set fra Syd.

andre end Skolen, thi Biblioteket skulde forøges betydeligt, aabnes for Publikum og "for Flensborg indtage den Plads, som Universitetsbiblioteket har for København".

Som Følge heraf ændrede Winstrup sine Planer og ind- 
sendte et alternativt Forslag. ${ }^{24}$ ) I det første beholdt han Hjørnetaarnet mod Rødegade, medens han i det andet havde tænkt sig Observatoriet anbragt ovenpaa det gamle Taarn ved Porten over Klostergangen; fælles for begge Projekter er,

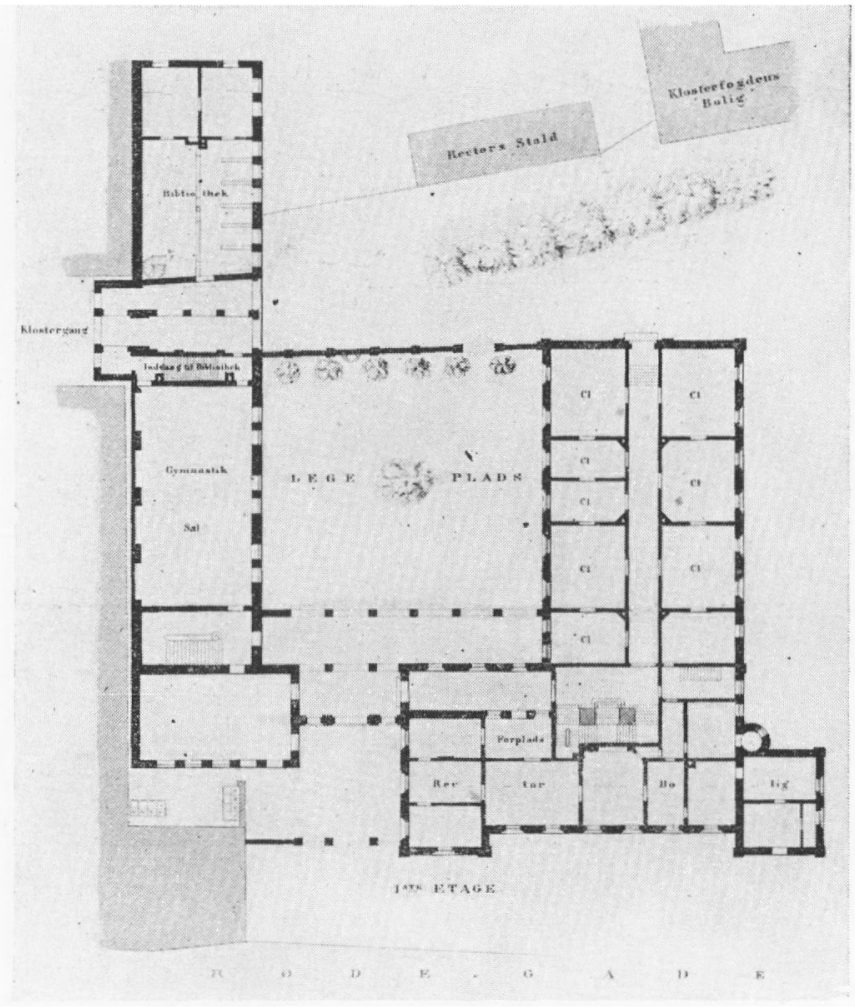

Afb. 17. Stueplan over Skolen i dens endelige Skikkelse.

at Biblioteket er flyttet hen $\mathrm{i}$ den gamle Rektorbolig øst for Klostergangen, hvor der ogsaa skulde være Oldsagssamling, og at han, for at skaffe mere Plads i den nye Skolebygning, har skudt en Risalit frem ved hver Ende af Facaden mod Rødegade: Winstrup vilde nødig opgive Taarnet, hvilket han ogsaa skrev til Regenburg. ${ }^{25}$ ) Planerne blev forelagt Kunstakademiet, der anbefalede. Taarnprojektet til Approbation — dog med det

24) Skr. 22/7 1856 fra W. til Simesen. (Sl. Min. Arkiv).

25) 27/7 1856. Regenburgs Arkiv. 
Forbehold, „at Bygningen i Udførelsen erholder mere Enhed i Stilen, end Tegningen udviser". ${ }^{26}$ ) Planen blev derefter den 19. Oktober 1856 godkendt af Kongen, der samtidig af den kongelige Kasse bevilgede ialt 65.000 Rdl. og af den Gotthard og Anna Hansenske Stiftelse 16.000 Rdl. til Skolens Opførelse, medens Flensborg By skulde udrede forskellige Erstatninger til Klosteret og afgive Grund til Genopførelse af Fattighuset. ${ }^{27}$ ) Paa samme Maade, som i Haderslev, var det altsaa Staten, der overtog Hovedparten af den økonomiske Byrde, medens Kommunen slap ret billigt.

I Foraaret 1857 begyndte man at grave Grunden til det nye Hus. Den 24. August s. A. - paa et Tidspunkt, da Murene allerede stod adskilligt over Jorden - blev Grundstenen nedlagt ved en Højtidelighed, hvor Taler og Sange paa Dansk og Tysk vekslede indbyrdes. ${ }^{28}$ ) Som ved den tilsvarende Højtidelighed i Haderslev i 1853 nedlagdes ogsaa her en af Winstrup tegnet Sølvplade over Mønter, slaaet under Fr. VII's Regering. Teksterne paa de to Plader svarer nøje til hinanden, men Flensborgpladen har faaet et mere kunstnerisk Præg end Pladen i Haderslev. Regenburg var nemlig anderledes lydhør for Winstrups Ønsker desangaaende end Rektor Thrige. ${ }^{29}$ ) Ovenover Teksten er $i$ et halvrundt Felt anbragt et Billede, tegnet af Lorenz Frölich (Afb. 18). Det forestiller Danmark, symboliseret ved en tronende Kvinde, der er omgivet af de tre danske Løver og holder Danebrog $\mathrm{i}$ den ene Haand, medens hun med den anden kalder Drengene hid til Undervisning (Paa Pigerne var der jo dengang ingen, som tænkte). Ved hendes Side staar Haabets Genius og i Baggrunden ses Nicolaj Kirke og Skibene i Havnen, Symbolet paa Byens aandelige og økonomiske Liv. I to runde Felter i de øverste Hjørner af Pladen er Sønderjyllands og Flensborgs Vaaben - uden Nældeblad — anbragte. Frølichs

28) $26 / 81856$.

27) Indbydelsesskrift p. XII.

28) Skoleprogram 1858 p. 10.

29) Skr. af 27/7. 1856 og $19 / 11$ s. A. fra W. til Reg. Regenburgs Arkiv. 
Tegning er iøvrigt omsat til et Glasmaleri, der siden 1941 har smykket Duborgskolens Festsal. ${ }^{30}$ )

Den 12. Oktober 1857 besøgte Fr. VII og Grevinde Danner

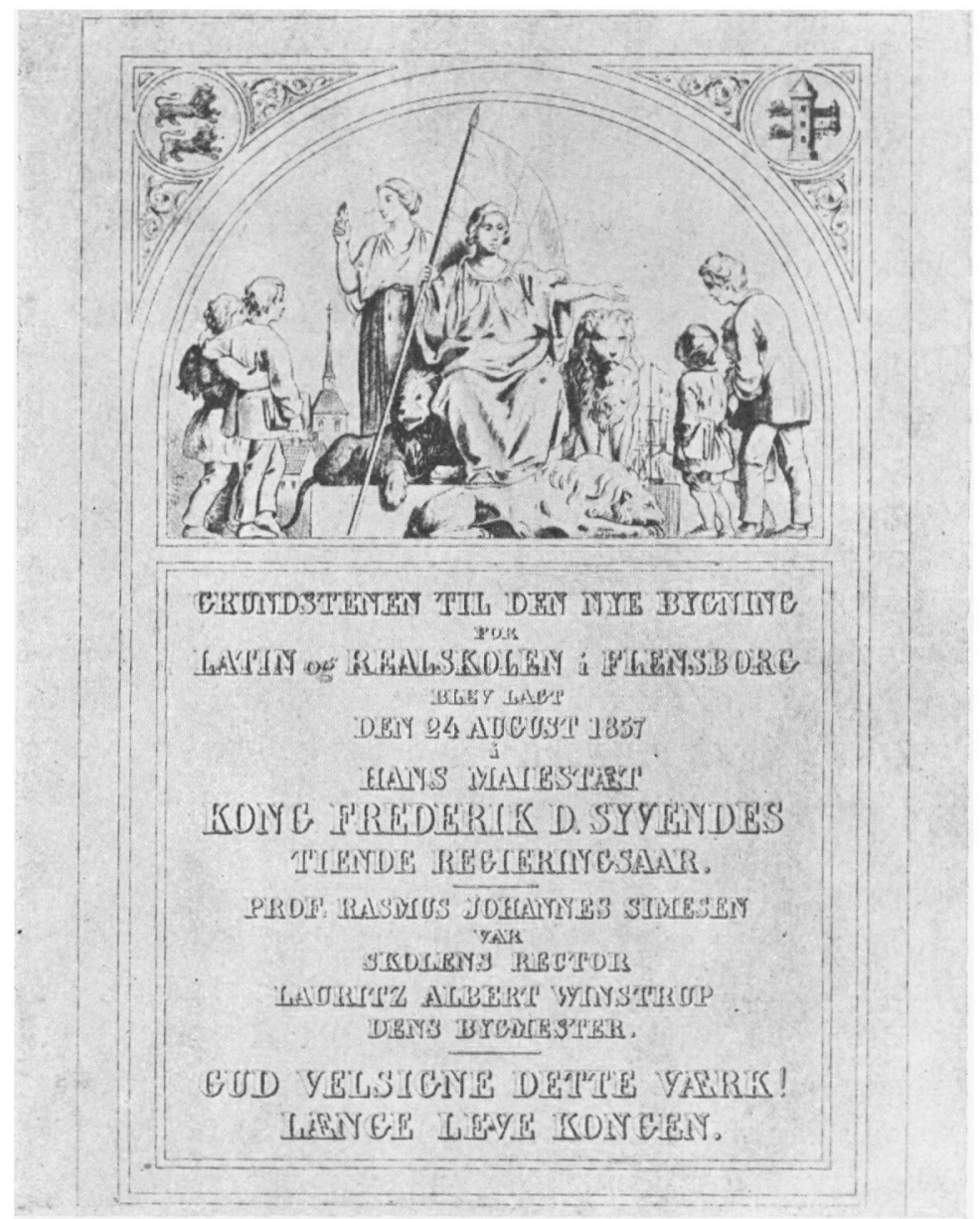

Afb. 18. Eølvplade. gengivende Tegning af L. Frølich, nedlagt med Grundstenen 1857.

Byggepladsen, hvor Winstrup forte om og foreviste Kongen sine Tegninger..$^{31}$ )

so) Se Duborgsamfundets Aarsskrift 1942 p. 53.

31) Skoleprogram 1858 p. 12. 
I Løbet af Efteraaret 1858 kunde den nye Bygning lidt efter lidt tages i Brug; herefter begyndte Ombygningen af den gamle Skole, som varede ved til Slutningen af $1860 .{ }^{32}$ ) Man ventede

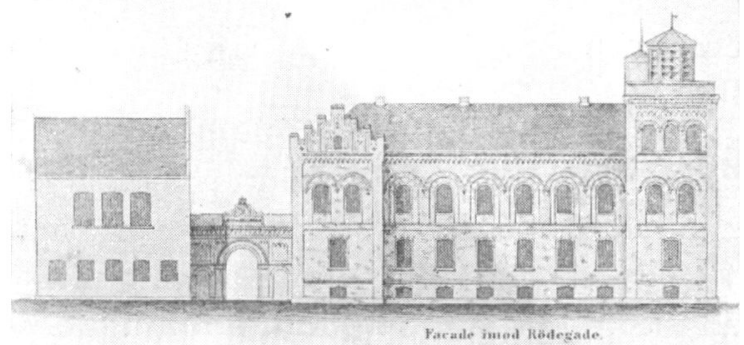

Afb. 19. Skolen 1860. Facade mod Rødegade. Jvi. Afb, 17.

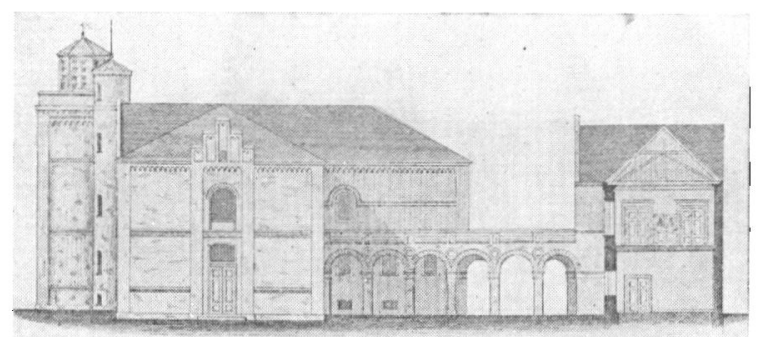

Afb. 20. Skolen 1860. Set fra Øst, med Snit gennem Nordfløjen, Jvf. Afb. 17 .

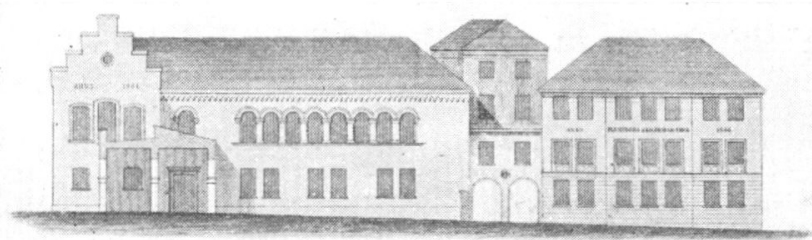

Forandrind af den gamle Skole

Afb 21. Skolen 1860. Nordfløjen. Jvf. Afb. 17.

imidlertid med Indvielsen til næste Aar i Haab om, at den kunde ske „in gnädiger, huldvoller Anwesenheit Seiner Majestät Königs Friedrich VII, dessen Werk ja das Gantze ist “. ${ }^{\text {s3) }}$ Dette Haab glippede imidlertid, da Kongen i 1861 opholdt sig

32) Indbydelsesskrift p. XIV.

33) Skoleprogram 1860 p. 91. 
kortere end sædvanligt i Sønderjylland. Den højtidelige Indvielse fandt endelig Sted Tirsdag den 8. Oktober 1861. Da havde Arbejdet ogsaa varet over 41/2 Aar, hvilket skyldtes Hensynet til Skolens Drift, som skulde foregaa nogenlunde upaavirket af Ombygningen.

Den Grund, man havde valgt til Byggeplads, dannede en skæv Firkant; den laa lavt, endda lavere end Rødegades Niveau. Allerede 1863 klages der da ogsaa over Fugt i Skolens Kældere. ${ }^{34}$ ) Mod Øst faldt Terrænet yderligere mod Mølleaaen.

Naar Winstrup havde flyttet Undervisningslokalerne bort fra den gamle Skolebygning, skyldtes det, at den ikke var synderlig dyb og kun fik Lys fra een Side og derfor ikke var velegnet til at indrettes til Klasser..$^{35}$ ) Medens det lange Hus hidtil havde staaet med samme Taghøjde i hele sin Længde (Afb. 13), blev det nu delt $i$ to Blokke paa hver Side af Portgennemkørselen, (Afb. 17 samt 19-21), mod Vest en toetages Bygning, indeholdende Gymnastik- og Solemnitetssal, mod Øst en treetages Bygning, der helt var overladt til Biblioteket - Oldsagssamlingen var nu installeret i Stænderbygningen - og som med sit afvalmede Tag fremtraadte som et selvstændigt Led i det hele. Facadebehandlingen var ogsaa forskellig; i Biblioteket Klassicisme, medens den anden Blok med sine 6 firkantede Vinduer i nederste Etage og ovenover et Galleri af 8 sammenhængende rundbuede Vinduer nærmest ledte Tanken hen paa et Renaissancepalads. Delingen er bevidst gennemført. „Det er mig af Vigtighed at have en bestemt Adskillelse imellem Solemnitetslocalet og Biblioteket for at undgaa det kjedelige i den lange Bygning og saa meget som muligt give hver Del sit characteristiske Ydre", hedder det i et Brev til Regenburg. ${ }^{36}$ ) Ved Delingen havde Winstrup tillige faaet skjult Terrænets Hældning, som man ikke havde kunnet undgaa at bemærke paa den lange Facade.

34) Kionc. Skr. 18/3 1863 fra W. til Min. f. Sl. - W.'s Arkiv.

35) Skr. Febr. 1856 fra W. til Regenburg. (Regenburgs Arkiv).

s6) $27 / 71856$ fra W. til R. Regenburgs Arkiv. 
Winstrup havde i lang Tid været i Tvivl om, hvorledes han skulde forholde sig med Gennemkørselen. Paa en Tegning fra Januar 1854 havde han tænkt sig Observatoriet anbragt her, og det havde ogsaa været hans Tanke efter Planen af November s. A. Derimod havde han efter Planen Januar 1856 tænkt sig de to Bygningsdele forbundne ved en Bue (Afb. 16,a), og dette gaar igen paa det antagne Projekt af Juli 1856 (Afb. 16,b), medens han som omtalt paa det samtidige, ikke antagne Projekt paany havde tænkt sig Observatoriet anbragt her. Hans Planer var dog ikke endelige, idet han havde forbeholdt sig til sin Tid at fremkomme med nærmere Forslag. ${ }^{37}$ ) Forst i Januar 1859 har han saa udarbejdet de Tegninger, hvorefter Arbejdet blev udført.

Det taarnagtige Fremspring blev forhøjet en Etage (Afb. 21) og traadte nu frit frem, idet saavel Taget som den øverste Etage paa Bygningen bag ved blev brudt ned. Skolen fik følgelig saaledes 2 Taarme, Observatoriet paa den nye Skolebygning mod Rødegade og Lydtke Namensens Taarn, der dannede en karakteristisk og værdig Afslutning paa Klostergangen; nederst stod det i Rustica, gennembrudt af 3 Aabninger, den store Vognport og 2 mindre Indgange ved Siderne, derefter fulgte den glatte og pudsede Facade og overst oppe det flade og afvalmede Tag. Taarnet var fuldt og helt i Klassicismens Aand ligesom Biblioteket. Den vestlige af Sideportene førte til en Trappe, ad hvilken man kom op til Biblioteket, den østlige var beregnet til Gennemgang forFodgængere (Grundplanen Afb. 17) og udvidede sig længere inde tragtformigt, saaledes at den fik samme Højde og Bredde som Vognporten. Ved dette Trick havde Winstrup opnaaet en fortrinlig Virkning, set fra Syd: En Dipylon, en Dobbeltport, som rejste sig med to høje, runde Buer under en flad Ballustrade, bag hvilken atter Taarnet hævede sig, ganske vist skævt forskudt i Forhold til Dipylon, hvilket dog paa en behændig Maade blev kamoufleret (Afb. 21).

37) Skr. 27/7 1856 fra W. til Reg. Regenburgs Arkiv. 
Gymnastik- og Solemnitetssalene var hver 30 Alen lange og 14 Alen brede. I Solemnitetssalen var Loftsbjælkerne synlige og ligesom Mellemrummene mellem Bjælkerne dekorerede med forskellige Ornamenter. Ved den østre Ende stod Katederet, paa den vestre hang Billeder af Namensen og Borgmester Geerdt v. Meerfeldt, Skolens Stifter og Velgører, og ovenover disse anbragtes en Buste af Fr. VII. Iøvrigt hedder det i Indbydelsesskriftet i Anledning af Skolens Indvielse, at „Salens yderligere Decoration er forbeholdt en senere Tid", og hvad der er ment hermed, fremgaar tilstækkeligt tydeligt af en Skitse af Winstrup, hvor han bag Talerstolen har tænkt sig Frølichs store Thyra Danebods Billede anbragt i stort Format, vel i samme Størrelse som Billederne i Appellationsretten (Afb. 22). ${ }^{\text {s8 }}$ )

Det maatte unægteligt have virket manende paa Drengene, naar de samledes i Salen, at staa overfor et saa ædelt Kunstværk, der ligesom illustrerede de Ord, der var blevet sunget ved Grundstensnedlæggelsen, at Skolen ikke var bygget af Sten alene, „men af Glød og Hjerter unge og af danske Ord paa Tunge“ og derfor skulde være som et "Aandens Danevirke“. ${ }^{\text {(9) }}$ ) Men Krigen i 1864 hindrede, at Planen nogensinde blev realiseret.

I den i 1854 opførte Tværfløj blev den tidligere Solemnitetssal nu Sanglokale, og i Gymnastiksalen underneden blev indrettet Lokale til Naturfagene. Herfra var let Adgang til Rødegade, hvilket var praktisk, da det var Meningen at benytte Lokalet til populxrvidenskabelige Foredrag. I November Maaned 1861 kastede Rektor Simesen sig da ogsaa ud i to Foredragsserier: „Physik for Herrer og Damer" og "Mathematik for de Herrer, de kunde ønske at fortsætte, hvad de tidligere have lært" $\left.{ }^{40}{ }^{40}\right)$

Det gamle og det nye Skolehus stødte ikke sammen, men var kun forbundne med en Vestibule og en Buegang paa 6 Fag,

38) Indbydelsesskrift p. XVI.

39) Skoleprogram 1858 p. 12.

10) Skr. 22/10 1861 fra Simesen til Regenburg. 
der løb langs med Vestfløjene ind mod Skolegaarden og gav Ly for Eleverne i daarligt Vejr (Grundplan Afb. 17 og Afb. 20). Efter alt at dømme har Winstrup sat megen Pris paa Buegange; fra hans Skoletid foreligger der flere Projekter med saadanne Gange, ligesom han ogsaa havde tænkt sig Skibbrogaden i

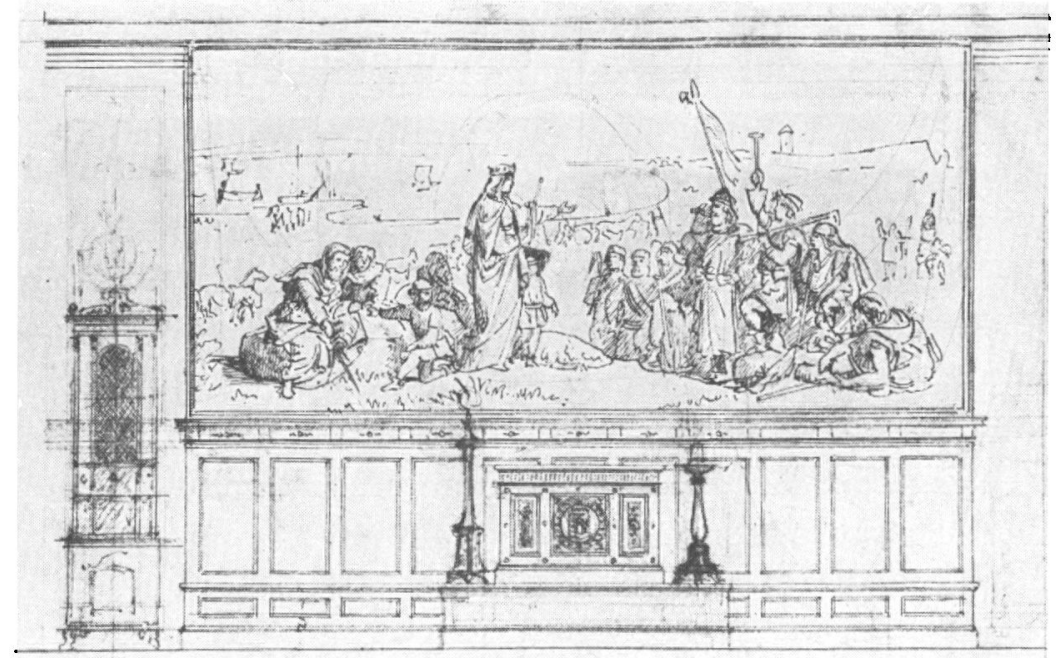

Afb. 22. Skolens Solemnitetssal. Skitse af Winstrup til Talerstol og Dekoration af Bagvaggen med L. Frolichs Dannevirkebillede.

Flensborg udvidet med en Buegang, bag hvilken der skulde indrettes Butikker. Motivet er velkendt fra vore Slotte og vore Klostre, men har aldrig tidligere været bragt i Anvendelse ved en Skole. ${ }^{41}$ ) Flensborg Latin- og Realskole er imidlertid den eneste Skole indtil 1920'erne, der har haft Buegang; først da blev dette Bygningsled atter indført - undertiden varieret som Søjlegang - ved de store Statsskoler i Viborg, Randers og den ombyggede Roskilde Katedralskole. Ogsaa den nye Duborgskole prydes med en Buegang langs Hovedfacaden.

Skolens nye Hovedindgang laa imellem det nye og gamle Skolehus ud mod Rødegàde. Gennem en smuk tredelt Portal,

11) Her bortses fra Sorø Akademi for Branden og Herlufsholm, der jo var ombyggede Klostre. 
prydet med Fr. VII.'s kronede Navnetræk og Indskriften „Latin- og Realskole 1860“, kom man gennem en lille Gaard til den omtalte Vestibule, hvorfra man ved at dreje til højre kom ind i den nye Skole (Afb. 17, Afb. 19).

Det nye Skolehus havde Hovedfacade mod Rødegade (Afb. 19); det laa noget tilbagetrukket paa Gadens Bebyggelse, men kom iøvrigt ikke rigtig til sin Ret paa Grund af den lave Beliggenhed. Facaden er tredelt; den bestaar af et tilbagetrukket Midterparti og to fremspringende Sidefløje, af hvilke den nordlige ender med en kamtakket Gavl, medens den anden fortsætter taarnagtigt med endnu en Etage og afsluttes med et fladt Tag, hvorpaa Observatoriet var anbragt. I sin Beskrivelse har Winstrup meget stærkt fremhævet Nødvendigheden af at placere et Taarn, hvor de to Fløje støder sammen; Taarnet kunde kun være halvt saa dybt som Huset, thi en større Dybde vilde medføre, at visse af Værelserne blev uden Vinduer (se Grundplanen Afb. 17); hvis man nu vilde give Taarnet en Afslutning, svarende til den nordlige Risalit, d. v. s. lade det afslutte med en Kamgavl, maatte der ogsaa opføres en tilsvarende Gavl paa Taarnets østre Side, og det vilde da blive vanskeligt at bringe denne i Forbindelse med Fløjene. „Taarnmuren afslutter derimod Taget paa den simpleste og naturligste Maadex.42)

Kælderen i Hovedfløjen optoges af Pedellens Lejlighed, Køkken, Pige- og Spisekammer til Rektors Lejlighed. I Sydfløjen var der Brændselskældere og ligesom i Haderslev et kemisk Laboratorium.

I Stuen og paa 1. Sal optoges alle Værelser ud mod Gaden af henholdsvis Rektorboligen og Fysiksamlingen; det eneste egentlige Undervisningsrum, der vendte ud til Gaden, var det fysiske Auditorium. For at forstaa dette Forhold, maa man huske, at Rødegade var stærkt trafikeret, og at hver Gang en af Vognene rumlede over Rødegade, vilde al Undervisning væ-

42) 27/7 1856 fra W. til Simesen. Sl. Min. Arkiv 
re umulig i Værelserne ud til Gaden.. ${ }^{\text {(3) }}$ Københavns Universitet og en Række af de ældre Latinskoler har da ogsaa af denne Grund Korridoren ud mod Gaden og Undervisningslokalerne ind mod Gaarden, fjernt fra al Støj. Først i vor Tid med Asfaltbrolægning og Gummihjul har vi nogenlunde kunnet gøre os til Herre over Støjproblemet.

De egentlige Klasseværelser - ialt 18 - er derfor saavel i Stuen som paa første Sal samlede om Midtkorridoren i Sydfløjen; de fleste var paa 2 Fag, enkelte paa 1 Fag. Klasseværelsernes vekslende Størrelse var en Arv fra Haderslev. Hovedtrappen laa inde i Bygningen og fik sit Lys gennem Vinduer i Taget.

Om Formiddagen den 8. Oktober 1861 fandt den højtidelige Indvielse af Skolen Sted; atter veksledes dansk og tysk Sprog. Om Aftenen var der Bal for Elever og Lærere, Embedsmændene og de Haandværkere, som havde haft med Opførelsen at gøre - ialt ca. 900 Personer; det kan ikke ses, om Winstrup har været til Stede. Der blev danset i Fest- og Gymnastiksalen, Sangsalen og Naturhistorieværelset. ${ }^{44}$ ) I en af Festsangene gives en morsom Beskrivelse af Bygningen:

(Mel.: \& köra Vatten ....)

Men det er ogsaa en prægtig Sal, som Kongen her har ladet bygge, og lys er Klassen, og høj og sval og liflig Buegangens Skygge.

Fra Taarnet man paa Stjernehæren ser, i Kjældren boer Chemi - og meget mer,

Bagerne er her,

Skarp skydes der, og fine Træer gror paa Pladsen.45)

Med Rette kunde Winstrup være stolt af sit Værk; de Ord, der var faldet i Dagens Løb, "dieser neuen, schönen Räume“, "diese Prachtgebäude", "dette stolte Hus"46) var ikke Munds-

4s) Se Indbydelsesskriftet p. XV.

44) Se nærmere Skoleprogrammet 1862 p. 18-40.

45) Skoleprogram 1862 p. 38 . Under Regnskabsoversigten p. 43 omtales Udgiften Skydeøvelser 37 Rdl., 4 Mk., 15 Sk.

46) Program 1862 p. 12 - smst. p. 31. 
vejr. Og der var en dyb Sandhed i Ordene, naar Subrektoren skrev, at „Flensburg jetzt wirklich zwei grosse herrliche Schulgebäude ...... besitzt, wie deren wenige andere, grössere Städte wohl aufzuweisen haben ".77) Ingen af Hertugdømmets Byer kunde naturligvis komme i Betragtning. Men heller ikke i Kongeriget fandtes tilsvarende Bygninger, end ikke i Hovedstaden. Dette hænger sammen med, at Midlerne til Skolerne i Kongeriget skulde bevilges af Rigsdagen, hvor der netop i disse Aar indenfor visse Kredse var stærk Modstand mod „den sorte Skole“, ligesom man ud fra en liberalistisk Anskuelse mente, at den højere Undervisning bedre og billigere kunde overlades til det private Initiativ. ${ }^{48}$ )

Syd for Kongeaaen kunde Kongen bevilge uden at spørge Stænderne; man kæmpede en Kulturkamp og var ogsaa villig til at ofre, hvad det kostede; derfor lettede man baade i Haderslev og Flensborg de betrængte Kommunekasser for Byrderne ved de store kostbare Skoleforetagender. De private Skoler, der kunde være Tilholdssted for den slesvig-holstenske Oprørsaand, saa man skævt til,,$^{49}$ ) og den offentlige Undervisning maatte følgelig gøres saa god, som muligt, saa Forældrene naturligt sendte deres Børn i de offentlige Skoler. Af disse Grunde var det, Winstrup fik betroet en Opgave, som ingen Arkitekt vilde faa stillet Nord for Kongeaaen. Hvordan Opgaven er løst, er skildret ovenfor, og det vil deraf fremgaa, at han paa mange Maader var forud for sin Tid, - Buegangen, Observatoriet, paatænkt Maleri af Frølich o. s. v.; men naturligvis var der ogsaa Mangler; Adgangen til Biblioteket ad den venstre Sideport, naar Biblioteket laa øst for Porten, var ikke let at finde ud af for uindviede, at man skulde gennem Lærerværelset for at komme til Fysiksamlingen, var upraktisk osv.

De Forhaabninger, man havde stillet til Skolen som et Fristed for dansk Aand, fik en brat Ende i 1864; Rektor og Lærere

47) Skoleprogram 1860 p. 90.

48) V. Lorenzen i Metropolitanerbogen 1939 p. 141 o. flg.

19) Se Hjelholt: Anf. V. p. 130, 176 o. flg. 
blev afskedigede, og da Skolen efter Paaske 1864 genaabnede foreløbig i lejede Lokaler, da Skolebygningen blev brugt som Lazaret - var det som en tysksproget Undervisningsanstalt; ${ }^{50}$ ) der vedblev dog under vekslende Kaar at blive givet Undervisning i Dansk lige til 1889, da de sidste Rester forsvandt. ${ }^{\text {sl) }}$

Selve Bygningen vedblev at være i Brug som Latinskole til 1920 , da det nye Gymnasium paa Øvelgønne blev taget i Brug paa det Strøg, man i 1855 var veget tilbage fra at bygge paa. ${ }^{52}$ ) Gymnasiet blev opført i Aarene 1912-14, men havde under Verdenskrigen været benyttet af Militæret, bl. a. som Internat for danske Nordslesvigere. I Aarene 1922-24 rejste der sig paa Duborg Banke en ny herlig dansk Skole, som paa mange Maader har ført Traditionerne fra Winstrups Bygning videre; $i$ det indre er den prydet med Malthe Engelsteds Kartoner til Frølichs historiske Billeder, men endnu mangler en Gengivelse af Thyra Danebod-Billedet, der med Rette vilde høre hjemme her.

Med den gamle Latinskole er der handlet sørgeligt; i Rektors Have er der rejst en Husholdningsskole. Biblioteket og Gennemkørselen, disse interessante Træk fra den ældste Latinskole, er borte. Festsalen og Gymnastiksalen opdelt i mindre Værelser, Buegangen delvis nedrevet, Observatoriet fjernet o. s. v. Skolen benyttes nu som Handelsskole. ${ }^{53}$ )

VII.

De danske Borgerskoler i Flensborg.

Samtidig med Arbejderne paa Latinskolen havde Winstrup bygget to danske Borgerskoler i Flensborg. Skønt Flensborg gennem lange Tider havde været en baade dansk- og tysktalende By og havde ligget omgivet af et dansktalende Opland, er det dog en sørgelig Kendsgerning, at der inden Treaarskri-

s0) Reinhard Kunkel i »Der Schlewig-Holsteiner 1941 p. 118.

s1) Harald Skalberg: Undervisningen i Dansk .... i Hertugdømmernes lærde Skoler efter 1864, Kbh. 1932 p. 15.

s2) Kunkel p. 119. Skolen.

5s) Der Schleswig-Holsteiner 1941 indeholder flere Afbildninger af 
gen ikke fandtes en eneste dansk Skole i Byen, og at der i Byens tyske Skoler kun gaves en meget begrænset og kummerlig Undervisning i Dansk. Men den 9. Januar 1852 aabnedes i Tilknytning til den frie danske Menighed en dansk Skole med 27 Elever; den havde tilhuse i lejede Lokaler, bestaaende af 3

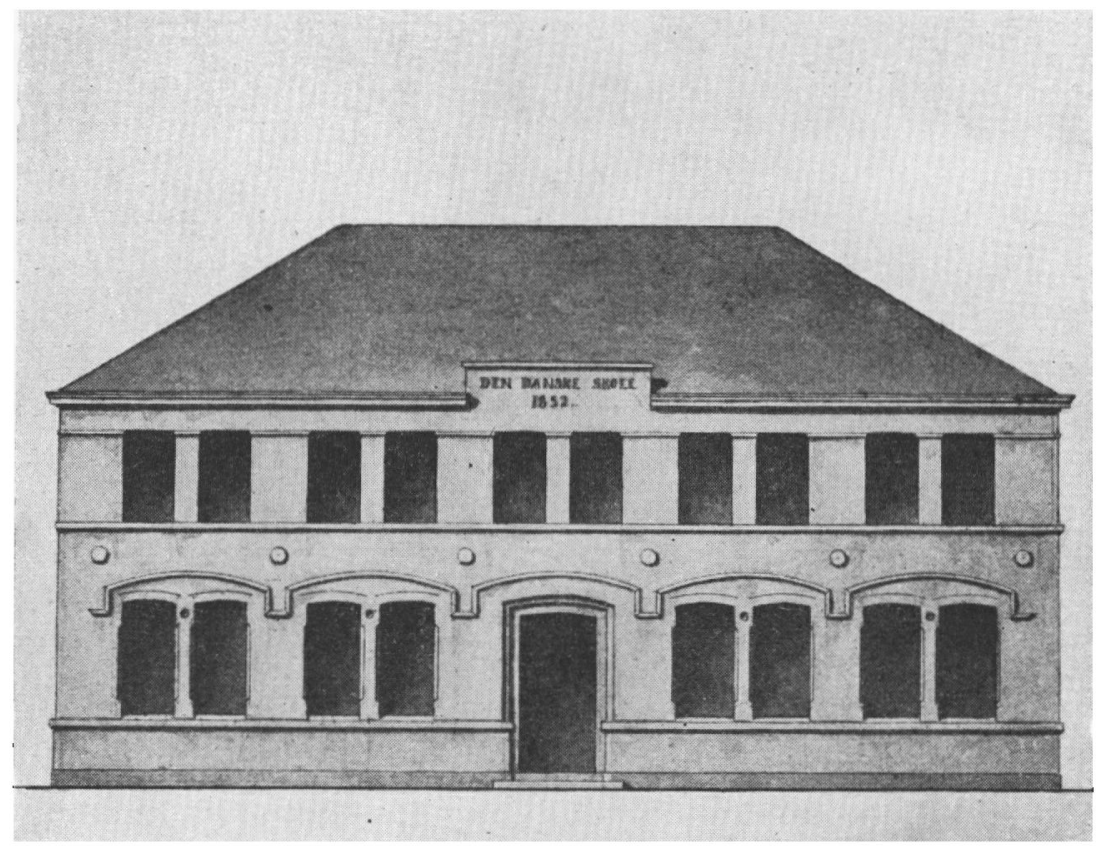

Afb. 23. Forslag A til Den Danske Skole i Flensborg 1852.

Værelser, hvoraf det ene var uden Kakkelovn. Skolen voksede og havde pr. 1. April 1852 over 60 Børn. ${ }^{1}$ )

For at skaffe den ordentlige Lokaler henvendte Præsten ved den danske Helligaandskirke, Gomme Frederik Graae, sig til Winstrup angaaende et Udkast til en Nybygning. ${ }^{2}$ ) Winstrup udarbejdede i Løbet af November Maaned to Forslag, A og B.')

1) G. Fr. Ax Graae: Mellem Krigene, Kbh. 1887.

2) Graae pag. 156

3) 26/11 1852 fra W. til Graae, Slesv. Min. Arkiv, Pakken: Dansk Kirke og Skole i Flensborg By og Provsti. 
Fælles for dem begge er, at Skolen var tænkt placeret bag ved Helligaandsgangen i "Gravene" paa en Grund,der blev benyttet som Have.) Ifølge det første Forslag (Afb. 23) var Skolen tænkt indrettet $i$ en langstrakt, 2-etages Bygning, dækket af et afvalmet Tag. Nederste Etage skulde indrettes til 4 Klasseværelser, grupperet omkring Trappen. Paa 1 . Sal skulde dels være Plads til Lejlighed for Kateketen og en Lærer, dels til Biblioteket, saaledes at dette Rum tillige kunde benyttes som Samlingsværelse, Forsamlings- og Solemnitetssal, og, naar Skolen engang maatte trænge til Udvidelse, da til Klasseværelse. Udgifterne ifølge denne Plan vilde beløbe sig til 11.000 Rdl. Medens Bygningen ifølge Forslag $\mathrm{A}$ har sin største Udstrækning paa langs, strækker den sig ifølge Forslag B i Vejret. De to nederste Etager skulde hver indeholde 2 Klasseværelser, anbragte paa hver sin Side af Trappen, og tredie Etage var tænkt indrettet til Bolig for Kateketen, medens der hverken var afsat Plads til Bolig for Andenlæreren eller Værelse for Biblioteket, hvorfor Udgifterne da ogsaa kun vilde beløbe sig til $9.600 \mathrm{Rdl}$.

Ingen af disse Planer blev nogensinde realiserede af den simple Grund, at Menigheden ikke havde Penge at bygge for og derfor maatte spare det mest mulige. Samtidig trak Sagen i Langdrag ved, at en Privatmand havde gjort Krav paa den paatænkte Grund „hvilken Trætte først fik sin Løsning i Skolens Favør i Foraaret 1854“.5)

Herefter lod Graae Winstrup udarbejde et tredie og billigere Projekt, der i Virkeligheden blot er Forslag B yderligere reduceret. Som ved dette er nederste Etage indrettet til 2 Skolestuer paa hver Side af Trappen, men paa 2. Etage er kun 1 Skolestue, medens Resten optages af Kateketens Lejlighed, der tillige omfattede 3 Værelser paa Loftet med Vinduer i Gavlene og i Kvisten paa Hovedfacaden.') Naar man

4) Konc. t. Skr. $23 / 253$ fra W. til Magistraten. W.'s Arkiv: Flensborg i Almindelighed.

5) Skr. 4/3 1853 fra Mag. i Flensborg til Slesv. Min. Sl. Min.'s Arkiv.

6) Skr. 9/? 1854 fra Graae til Kirkeministeriet. 
kunde undvære Lejlighed til Andenlæreren og Biblioteksværelset, hang det sammen med, at der var bevilget Huslejegodtgorelse til Præsten, der som Følge heraf fraflyttede Præstegaarden i Helligaandsgangen, i hvilken der blev indrettet Lærerbolig og Bibliotek.Byggegrunden skænkede Magistraten, og de egentlige Byggeudgifter, 8000 Rdl., blev dækket saaledes, at Fr. VII bevilgede 5000 Rdl. af den Carstenske Fond, Magistraten 2000 Rdl. af Gotthard og Anna Hansens Stiftelse, medens de manglende $1000 \mathrm{Rdl}$. skulde kunne optages som Laan ag afdrages $\mathbf{i}$ 28 paa hinanden følgende Aar. $\left.{ }^{7}\right)$ Da der imidlertid viste sig Vanskeligheder ved at dække dette Laan, blev Beløbet ved allerhøjeste Resolution af 14/12 1854 bevilget af den Carstensenske Stiftelse. ${ }^{3}$ )

Den 17. Juli $1854 \mathrm{blev}$ den reducerede Byggeplan approberet, og i August Maaned blev der sluttet Akkord med Haandværkerne. Da indtraadte der en ny Hindring.') Bygningskommissionen havde fundet paa at anlægge en Gade med 2 Husrækker i Gravene og med Udgang i Helligaandsgangen, hvilket vilde bevirke, at Skolen ikke som paatænkt kunde placeres for Enden af Gravene som Point de Vue for denne, men maatte anbringes ved Siden af den forlængede Gade med Gavlene mod Nord og Syd. ${ }^{10}$ ) Winstrup var Modstander af dette Gadeprojekt, ikke blot fordi det berørte Skolen, men fordi det paa det stærkt skraanende Terræn vilde være umuligt at bygge 2 Rækker Huse. Resultatet blev da ogsaa, at Deputeretkollegiet den 10. Oktober 1854 gik imod Bygningskommissionen, men hermed var Arbejdet rigtignok blevet sinket i 5 Uger. ${ }^{11}$ ) Inden Jul var Bygningen dog under Tag, og i Midten af April var den fuldt færdig.

Da Skolen fortsat voksede - i Foraaret 1857 var der 154

7) Se nærmere Fr. Graae: Zeitschrift der Gesellschaft für Schlesw. Holsteinische Geschichte Bd. 6 p. 317. - Skr. 14/6 1854 fra Kirkemin. til Slesv. Ministerium. Sl. M.'s Arkiv.

8) Resolutionsprot., sml. Skr. $18 / 121856$ fra Slesv. Min. til Kirkemin.

9) Graae pag. 161.

10) Konc. t. Skr. 24/9 1854 fra W. til Magistraten.

11) Konc. til Skr. 13/10 1854 fra W. til Mag. 
Elever ${ }^{12}$ ) - indgav Pastor Graae til Kirkeministeriet en Ansøgning om, at der burde „anskaffes, leies eller bygges et passende Locale i den nordlige Del af Byen henimod Nørreport", men fik Afslag, „da der med Hensyn til de tyske Borgerskoler i Flensborg var en meget større Trang til Udvidelse og Forøgelse af Skolelokalerne til Stede ". ${ }^{13}$ ) Pastor Graae lod sig ikke afskrække, men søgte først slesvigsk Ministerium om Hjælp til at leje et Lokale, og da det var bevilget, ${ }^{14}$ ) indgav han den $27 / 8$ 1857 et Andragende til Staten om Understøttelse „til Opførelsen af en passende Skole for de lavere Klasser, som paa Grund af de lokale Forhold burde henlægges til den nordlige Del af Byen, men forøvrigt maa betragtes som en Filial af den danske Borgerskole ved Helligaandskirken". ${ }^{15}$ ) Den paatænkte Skole skulde ligge paa en Kommunen tilhørende Grund udenfor Nørreport $i$ en af de saakaldte Politihaver, og Graae havde allerede bedt Winstrup udarbejde Tegninger til Bygningen. Disse var færdige i Løbet af September 1857. Den nye Skole skulde indrettes efter samme System som den gamle. I underste Etage var to Skoleklasser, i den øverste Bolig for en Lærer, bestaaende af 3 Værelser og 1 Pigekammer samt et Værelse paa Loftet, desuden to Værelser for en ugift Lærer og et reserveret Værelse.

I Løbet af 1857 indtraf den store Pengekrise, der lammede alt Byggeri; ${ }^{16}$ ) Winstrup benyttede sig af Chancen og fik købt Sten til 9 Rdl. 3 Sk. pr. 1000 Stk., medens Priserne ellers laa paa 12,13 Rdl. $^{17}$ )

Den 28/12 1857 bevilgede Ministeriet $10.000 \mathrm{Rdl}$. af den Carstensenske Stiftelse og Graae takkede hjerteligt Regenburg for "de 10.000 Hjælpetropper til den nordre Skoleskanse“. Med Magistratens Bevilling af Byggepladsen trak det derimod noget

\footnotetext{
12) Graae pag. 173.

13) Graae p. 179, Kirkemin.'s Skr. er dateret 19/4 1857.

14) Kgl. Res. 18/5 1857 .

15) Graae p. 180.

16) Skr. 24/12 1854 fra W. til Regenburg. Regenb.'s Arkiv.

17) Skr. $13 / 11858$ fra W. til Regenb.
} 
ud, idet man ingen Erklæring vilde afgive, før der var udarbejdet en Plan til Bebyggelsen af Kvarteret udenfor Nørreport. Winstrup maatte derfor udarbejde en saadan Plan, hvorefter Grundene øst for Aabenraa-Vejen skulde udstykkes i Karreer efter Skakbrætsystemet. ${ }^{18}$ ) Den 26. Januar 1858 godkendte Ministeriet Byggeplanen til Skolen, og i Begyndelsen af Oktober 1858 kunde den nye Bygning tages i Brug. ${ }^{19}$ )

Skolen voksede stadig og Klasserne blev paany overfyldte; $i$ den ene af de 3 Elementarklasser var der over 100 Børn, "skønt der $i$ enhver til Tidens Tarv svarende Borgerskole kun burde findes $\mathrm{i}$ det højeste 60 Børn $\mathrm{i}$ en Klasse, saaledes som Tilfælde er i alle Kjøbenhavns Skoler" ${ }^{20}$ )

Da man i sin Tid havde valgt det reducerede Byggeprojekt til Skolen i Gravene, havde man tænkt sig engang med Tiden at kunne paabygge en Etage, „hvilket vilde kunne ske uden Vanskelighed, da den underste. Del af Bygningen opføres saa forsvarligt, at den kan bære en tredie Etage og desuden Kvisten og Gavlene gøres saa høje, at de kunne udvides til en hel Etage“. Denne Ombygningsplan blev nu atter gravet frem $;^{21}$ ) var den blevet realiseret, vilde Skolen altsaa have faaet en Skikkelse, svarende til det oprindelige Forslag B.

Ved kgl. Resolution af 20/9 1861 blev der tilstaaet $4000 \mathrm{Rdl}$. straks og $1000 \mathrm{Rdl}$. aarlig i 10 Aar til Udvidelse af den danske Menigheds Skolevæsen; Planen om Tilbygning maatte imidlertid opgives, da det viste sig, at Bunden ikke kunde bære og Bygningen var sunket. I Skolekommissionen blev det drøftet, hvorledes Pengene herefter skulde anvendes, men Medlemmerne havde „en sand Skræk for den gode Winstrup, som de grumme nødigt vilde have med at bestille, da han er dem for flot". $\left.{ }^{22}\right)$ Foreløbig nøjedes man derfor med at indrette sig i lejede Lokaler $i$ den søndre Del af Byen. Men i 1863 indgav

\footnotetext{
18) W. til Reg. 13/1 1858.

19) Graae p. 186.

20) Graae p. 196.

21) Skr. 9/5 1854 fra Graae til Kirkemin.

22) Fra sydslesvigske Præstegaarde.
} 
Skolekommissionen Andragende til Magistraten om en Byggeplads i denne Bydel, men Sagen gik først i Orden i Slutningen af Aaret, saaledes at Winstrup næppe har naaet at udarbejde Tegninger til den nye Skole inden Okkupationen i 1864.

De to Skoler, Winstrup havde bygget, bestaar endnu. Skolen i Gravene har været katolsk Skole og for nylig Gasskole, den anden indeholder et kommunalt Bibliotek; rent arkitektonisk set vil de næppe paakalde nogen umiddelbar Interesse, fattige som de ser ud med de snavsede Sten og det sorte Skifertag og uden Prydelser af synderlig Art; med sine Kviste og Gavle gør Skolen i Gravene endda et forvirret Indtryk, hvad der altsaa skyldes dens særlige Bygningshistorie. Efter vore Begreber har Skolerne kun været primitive, uden Gymnastiksale og Lokaler til Særundervisning, endsige Bad, Tandklinik og andet, som nu hører til en moderne Undervisningsanstalt. De har næppe heller fra først af staaet Maal med de Bygninger, der samtidig blev rejst i København, og dog fandt man i Flensborg, at Winstrup var for flot. Sagen var den, at de danske Skoler stod langt over de tyske sammesteds, hvor der gennemsnitligt fandtes 83 Elever i hver Klasse mod 63 i de danske. ${ }^{23}$ ) Naar man ser paa Winstrups Tegninger til den tyske Johannesskole, vil man da ogsaa bemærke, at Klasseværelserne er indrettet til at kunne rumme langt flere Elever. Men denne Forskel blev af de danske Myndigheder benyttet som et Aktiv i den nationale Kamp. „Mærke Flensborgerne først, at vore Skoler ere lige saa overfyldte som de andre Skoler, saa er det forbi med Tilliden og Tilvæxten. “24) 60 Elever, som Pastor Graae vilde anse for det normale $i$ en Klasse, er efter vore Begreber altfor mange, men dengang synes man ikke i Sønderjylland at have været betænkelig ved at gaa endnu højere op, for da Borgmester Lund i Aabenraa i 1863 bad Winstrup om at gøre Udkast til en Pigeskole paa den tidligere Rektorskoles Plads,

23) Hjelholt p. 168.

24) Skr. 5/12 1859 fra Graae til Regenburg. Gengivet hos Hjelholt p. 168 i Noten. 
d. v. s. SV. for Nicolaj Kirke, forlangte han udtrykkelig, at der skulde være „4 Læsestuer, hver især store nok til at kunne rumme 80-90 Børn." ${ }^{\text {"25) }}$ Heller ikke dette Projekt naaede Winstrup at faa udarbejdet.

De danske Borgerskolers store Succes hvade smittet i Slesvig. Her havde Pastor Høyer Møller faaet oprettet en dansk Garnisonsskole, der i Januar $18 \overline{5} 5$ aabnede med 29 Elever og i 1863 var oppe paa $125 .{ }^{26}$ ) Den havde til Huse i et lejet Lokale, som imidlertid var "meget slet" og „mere fuld af Ulemper og Ubehageligheder end Sagen kan være tjent med“. ${ }^{27}$ ) I 1859 havde Høyer Møller modtaget Tilbud om en Byggeplads og satte sig straks i Forbindelse med Winstrup angaaende „den Sag, den danske, for hvilken vi begge stride" med Anmodning om, at han vilde besigtige Grunden. „Den gamle Feltpræst" saa allerede i Aanden, at der vilde rejse sig en ny Bygning, som skulde „staa i det tyske Slesvig med stor Indskrift“: „Kongelig Garnisonsskole“".25)

Winstrup fulgte Opfordringen og saa paa Grunden, men der kom intet ud af Sagen. Skolen maatte fremdeles nøjes med lejede Lokaler.

\section{VIII}

\section{Seminarierne i Tønder og Eckernførde.}

Der er en mærkelig Modsætning mellem den Handlekraft og Offervilje, som Regeringen havde lagt for Dagen ved Opførelsen af de to Latinskoler og Rejsningen af den danske Borgerskole i Flensborg og saa den langsommelige og forsigtige Fremgangsmaade og den Sparsommelighed, der udvistes ved Ombygningen af Tønder Seminarium og Indretningen af et Seminarium i Eckernførde.

\footnotetext{
25) Skr. 14/4 1863 fra Lund til W.

28) Hjelholt p. 164.

27) Skr. 22/6 1859 fra H. M. til W. i Lægget Gottorp Slotskirke.

28) Skr. 2/7 1859 fra H. M. til W.
} 
Skønt liggende $i$ det dansktalende Tønder var Undervisningssproget ved Seminariet dog Tysk. Dette ændredes, efter at Oprøret var nedkæmpet, og allerede den 30/7 1850 fik Forstander Bahnsen Meddelelse om, at Seminariet skulde være dansk og det tyske Seminarium flytte andetsteds hen, ${ }^{1}$ ) men først ved kgl. Resolution af 26/7 $1853 \mathrm{blev}$ denne Tanke realiseret, og først ved Paasketid 1855 var den tyske Undervisning afviklet. $\left.{ }^{2}\right)$

Herefter aabnedes 1857 et nyt tysk Seminarium i Eckernjørde i det tidligere Hotel Stadt Hamburg, som Winstrup forinden havde besigtiget efter Opfordring af Regenburg.') Winstrups Indberetning, der giver et fyldestgørende Indtryk af det gamle Provinshotel og dets Indretning, mundede ud i, at $\mathrm{K} ø-$ bet kunde anbefales, saafremt Bygningen kunde benyttes til Seminarium, uden at der skulde foretages store Forandringer, medens han i modsat Fald vilde tilraade Opførelse af en helt ny Bygning, selv om den blev dyrere, idet man herved ogsaa vilde opnaa en mere hensigtsmæssig Fordeling af Lokalerne. Ministeriet foretrak imidlertid Kobet af den gamle Gaard, som herefter var Seminarium i ca. 25 Aar og omkring Aarhundredskiftet blev nedrevet.

Efter Bortflytning af den tyske Afdeling stod Seminariebygningerne $i$ Tønder tomme. Siden 1828 havde Seminariet ligget paa Grunden Østergade Nr. 4, hvor det endnu ligger. Det bestod af Forstanderboligen og den egentlige Seminariebygning. ) Forstanderboligen, der var et toetages Hus af røde Mursten med afvalmet Tag var ældre end 1828, medens Seminariebygningen var opført noget efter dette Aar, det var et langt etetages Hus, forneden indrettet til 2 Klasseværelser, som blev adskilt af en lille Korridor; tilsammen kunde de 2 Værelser

1) Tønder Statsseminariums Historie $1788-1938$, Tønder 1938 p. 65 . Hjelholt p. 20.

2) Tønder Statsseminarium p. 67. teret.

3) Afbildning i Sdj. Historie IV p. 457. - Regenburgs Arkiv, uda-

4) Tønder Statsseminarium p. $\mathbf{4 3 .}$ 
rumme 80 Elever. Paa Loftet var 3 smalle og sikkert ret upraktiske Rum. Gymnastiksal fandtes ikke, men de gymnastiske $\varnothing v e l s e r$ blev foretaget $\mathrm{i}$ det frie. ${ }^{5}$ ) Bygningen var altsaa meget beskeden, og i 1847 havde man da ogsaa paatænkt en Ombygning, som Oprøret dog hindrede. I al deres Enkelthed havde de to Bygninger dog et smukt og stilfuldt Præg, som yderligere blev fremhævet ved de ioniske Søjler, der flankerede Indgangen.

Først den 4/8 1856 blev Winstrup officielt opfordret til at besigtige Bygningerne. $\left.{ }^{6}\right)$ Det viste sig nu, at Forstanderboligen var i høj Grad forfalden, hvorfor han da ogsaa foreslog den nedrevet og en ny Bolig opført paa Grunden. Seminariebygningen var som Følge af den lange Tid, den havde staaet ubenyttet, $\mathrm{i}$ temmelig forfalden Tilstand, men den kunde dog istandsæittes og skulde samtidig udvides ved en Tilbygning ud over den ene Ende, saaledes at den kunde rumme et Sangværelse, to Klasser og en Forstue samt i Tagetagen et Musikværelse, Plads til Samlingen og et Bibliotek. ${ }^{7}$ ) Foreløbig indskrænkede man sig til Omdannelsen af Seminariebygningen. Planen blev godkendt i Oktober 1856, og Arbejdet skulde derefter være færdigt til Kongens Besøg i’Tønder næste Aar, hvilket dog kun delvist lykkedes. Den 7/1 1858 kunde Tønder Statsseminarium aabne som dansksproget Undervisningsanstalt.") Winstrups Seminariebygning eksisterer ikke mere, idet den i 1905 blev nedrevet,") og Bedømmelsen af Værket maa derfor udelukkende ske paa Grundlag af gamle Tegninger samt et gammelt Lithographi. ${ }^{10}$ )

Da der kun havde fundet en Ombygning Sted, var Huset stadig præget af det ældre beskedne Anlæg fra 1830, men havde dog skiftet Præg derved, at den nu afsluttedes af fulde Gavle

\footnotetext{
5) Tønder Statsseminarium p. 45.

B) I Virkeligheden havde $W$. alt set dem.

7) Konc. til W.'s Indberetning 20/9 1856.

8) Trap- Slesvig 1864 Bd. I p. 135.

9) Tønder Statsseminarium p. 101.

10) Afbildet i Sdj. Hist. IV p. 455.
} 
i Modsætning til de delvis afvalmede Gavle, dels ved, at Indgangen havde mistet sine ioniske Søjler, Døren var blevet rundbuet og Indgangen markeredes af en beskeden, men nobel Renaissancekvist. Her havde Winstrup oprindelig tænkt sig et Ur og to Klokker anbragte, senere Hertugdømmets Vaaben og en Indskriftstavle, ${ }^{11}$ ) men selv disse beskedne Prydelser maatte han lade fare. ${ }^{12}$ ) Ligeledes maatte han opgive de paatænkte rundbuede Vinduer i Bygningens sydlige Ende. Som Bygningen fremtraadte efter \#ndringen, havde den faaet et hjemligt og hyggeligt Præg, hvori Traditionen fra vestslesvigsk Byggesæt klang igen.

Forst i Foraaret 1859 blev Planen til den nye Forstanderbolig godkendt, skent den blev anset for temmelig kostbar. ${ }^{13}$ ) Bygningen skulde kun være paa een Etage, men med Beboelse $i$ den brede Kvist og i Gavlene. Taget var af Skifer. Boligen staar endnu, men det skal ikke nægtes, at den for Nutidens Øje forekommer ret intetsigende, og at den gamle, enkle Empirebygning vilde have passet anderledes ind i Gadebilledet som Nabo til den ærværdige Hospitalsbygning.

Seminariets beskedne Karakter staar i Sammenhæng med dets Slægtskab med Landsbyskolen. Det vilde derfor have været af Interesse, om dette Afsnit om de Winstrupske Skolebygninger kunde slutte med Gennemgang af en Landsbyskole. Winstrup har da ogsaa flere Gange beskæftiget sig med Skolebyggeri paa Landet, idet Kirkevisitatoriet i Flensborg forelagde ham de Planer, som de lokale Bygmestre havde udarbejdet, til Gennemsyn. Materialet er dog ikke tilstrækkeligt til, at noget afgørende kan siges herom.

\section{IX. \\ Slotskapellet paa Gottorp.}

Efter Sejren ved Isted havde det danske Militær besat Sydslesvig, og rundt om i Kirkerne holdtes der dansk Feltgudstje-

11) Konc. til Skr. 24/3 1857 fra W. til Sl. Min.

12) Skr. 2/4 1857 fra Sl. Min. t. W.

13) Skr. 19/3 1859 fra Seminariedirektionen til W. 
neste. I Slesvig benyttede man den gamle ærværdige Sct. Michaelskirke, men da Sognets Ret gik forud for Militærets, var man nødt til at holde Gudstjeneste til andre Tider end de sædvanlige; en anden Ulempe var Kirkerummets „noget uhyggelige " Udseende.") Disse Mangler blev mere følelige efterhaanden som Gudstjenesterne paa dette Sted gik over til at blive en fast Institution, idet Pastor Høyer Møller hver Søndag prædikede for Militæret, de danske Embedsmænd og en lille Kreds af dansksindede Slesvigere.

Allerede i 1852 havde Høyer Møller tænkt paa at faa Slotskapellet paa Gottorp overladt til Brug ved de danske Gudstjenester, men da Slottet kort efter overfortes fra Civillisten til Krigsministeriet for at benyttes til Kaserne, viste Planen sig uigennemførlig, idet den stødte paa voldsom Modstand hos Krigsministeren C. F. Hansen, der vilde benytte Lokalet som Depot.')

Høyer Møller satte sig derefter i Forbindelse med Winstrup og fik ham til at gøre Tegning og Overslag, ikke alene til en Restaurering, men ogsaa til Anskaffelse af Døbefont og et nyt Orgel. Da saa Kongen i 1854 gæstede Gottorp, fandt man Lejligheden passende til at gøre et Fremskridt. General Bülow og Høyer Møller stod ved Alteret, da Kongen traadte ind i Kirken. Kongen saa sig om. Generalen bad da om at faa Kirken istandsat og fik da Svaret: „Ja, naturligvis, hvor er Hansen?“. Der løb straks en ud efter denne, der derpaa $i$ et yderst langsomt Tempo bevægede sig op ad Kirkegulvet. Da han kom nærmere, sagde Kongen: „Jeg vil have Kirken restaureret til Brug for Garnisonen", og idet han pegede op mod det gamle Orgel, hvor Hertug Fr. IV.'s Navnetræk stod, tilføjede han: „Der skal mit Navn staa“. Dertil svarede Ministeren koldblodigt: „Ja, har Deres Majestæt Penge?“ og vendte sig om og gik. Men da Høyer Møller gik ud af Kirken, kom Ministeren for Slesvig, Grev Carl

1) Høyer Møller: Livs- og Krigserindringer p. 110.

2) Livs- og Krigserindringer 112. 
Moltke hen til ham og sagde paa Dansk: „Hvorfor kan Kirken ikke blive istandsat? - Soldaten har da ogsaa en Sjæl “. ${ }^{3}$ )

Først efter at Minister Hansen i Slutningen af Aaret var gaaet af, kunde man begynde paa at faa Planen gennemført. I Efteraaret 1855 blev Winstrup officielt opfordret til at besigtige Kapellet, ${ }^{4}$ ) og den 6/3 1856 afgav han Indstilling. Da man imidlertid kun kunde afse 2000 Rdl. til Formaalet, maatte man foreløbig nøjes med at sætte Kirken i brugelig Stand. ${ }^{5}$ ) I Foraaret 1857 var disse Arbejder fuldført, saa den kunde benyttes til Gudstjeneste, naar det forlangtes. ${ }^{\theta}$ ) Indvielsen fandt Sted 12/4 1857; først derefter tog man fat paa de egentlige Restaureringsarbejder, som i det væsentlige var tilendebragt $1861 .^{7}$ )

Slotskapellet paa Gottorp er et firkantet hvælvet Rum i den nordlige Fløj; langs alle Sider løber et Galleri, der hviler paa Søjler; paa den ene Smalside bærer det Orgelet, paa den modsatte den pragtfulde hertugelige Stol; under denne staar Alteret, som blev adskilt fra den øvrige Kirke ved et Korgitter. Lukkede Stole stod mellem Væggene og Søjlerne, medens det firkantede Rum i Midten var tomt; Gulvet var belagt med Fliser, hvor store mørke Pletter talte deres uhyggelige Sprog om dengang, Kapellet benyttedes til Lighus for Lazarettet paa Gottorp.

Kapellet var et typisk Slotskapel, beregnet for Fyrsten og hans lille, men fornemme Følge; nu skulde det omdannes til Kirke for en Menighed med forholdsvis mange Medlemmer, men af langt jævnere Beskaffenhed. For at skaffe Plads til Tilhørerne blev der midt paa Gulvet opstillet Bænke „svarende til Kirkens Stil“. De lukkede Stole langs Siderne blev i det store og hele bibeholdt, dog at Dørene fjernedes og Mellemvæggene gjordes lavere. Et Par Stole, der stod i Vinduesnicherne

3) Livs- og Krigserindringer 114.

4) Skr. 30/9 1855 fra Ing. Korpset til W.

5) Skr. $29 / 81856$ fra Ing. Korpset til W.

6) Konc. 3/3 1857.

7) Livs- og Krigserindringer p. 116. 
paa begge Sider af Alteret, blev flyttet frem foran dette. Paa Galleriet blev der stillet Bænke; Høyer Møller vilde ogsaa have opstillet Bænke i den fyrstelige Stol, men dette maatte opgives, da Bjælkerne ikke kunde bære. Stolen blev derefter benyttet som Skriftestol.

For at gøre Luften i Kirken mindre raakold om Vinteren, blev store Dele af Flisegulvet brudt op. Forskellige Murerarbejder, Reparation af Træværket og af den fyrstelige Stol blev udført, ligesom alle Farver blev frisket op. I denne Forbindelse havde Winstrup stillet Forslag om at erstatte de tyske Indskrifter under Malerierne paa Galleriet med tilsvarende danske, „nu, da Gudstjenesten bliver dansk"; Omkostningerne herved vilde beløbe sig til 80 a 100 Rdl.; men Planen blev ikke gennemført; de tyske Indskrifter blev bevarede.

Derimod kom der dansk Paaskrift paa de nye Nummertavler; først fornylig er denne erstattet af en tysk Paaskrift, men bag Malingen kan man endnu skimte de gamle „Før" og „Efter Prædikenen“.

Orgelet var "saa usselt, som et Orgel kan være“". ${ }^{8}$ ) Det besluttedes derfor at lade Marcussen \& Søn i Aabenraa bygge et helt nyt og større Orgel, dog saaledes, at den gamle Orgelfacade, der gaar tilbage til 1567, men senere er ombygget omkring Aar 1700, blev bevaret og suppleret med nye Dele, der i Stil svarede til det gamle. Inden Planerne blev udført, blev de af Høyer Møller forelagt „gamle Bellmann“, d. v. s. Organisten ved Johannesklosteret, C. G. Bellmann, der havde komponeret Melodien til "Schleswig-Holstein meerumschlungen“.") Med ham var Høyer-Møller kommet i Forbindelse i Anledning af en Anmodning fra Musikforeningen om at laane nogle Noder, og Forbindelsen varede ved i 6 Aar til Bellmanns Ded. I sine Erindringer giver "den gamle Feltpræst" et meget sympatisk Billede af den over 80 Aar gamle Mester, der kun levede for sin Musik, og at netop han sagde god for Planerne, har sikkert væ-

8) Skr. 22/1 1856 fra Marcussen \& Søn, Aabenraa, til W.

9) Skr. 18/6 1858 fra H. M. til W. 
ret Høyer-Møller en Betryggelse. ${ }^{10}$ ) Den nye Orgelfacade blev kronet af det danske Rigsvaaben. ${ }^{11}$ ) I Begyndelsen af 1860 kunde Orgelet indvies. Alt $i$ alt maa det siges, at Winstrup har forstaaet at skabe et Hele af nyt og gammelt.

Korgitteret foran Alteret blev fjernet, og af de tiloversblevne Messingbalustre lavedes et nyt, halvrundt Knæfald ,af Hensyn til de mange Altergæster".

Altertavlen er af meget stor kunstnerisk Værdi; Materialet er Sølv og Ibenholt. Over et Fodstykke - Predellaen - hæver den sig, fast arkitektonisk opbygget i 3 Etager, hver indeholdende en Scene af Christi Ded og Oprejsning, fremstillet paa ophøjede og udhamrede Sølvplader. Imidlertid var Alteret i Tidens Løb blevet sørgeligt mishandlet, idet store Dele af Sølvdekorationerne var bortfjernede. Under Winstrups Ledelse blev det istandsat af Sølvsmed J. Boysen i Slesvig.

Paa Fodstykket var der kun et tomt Felt, hvor der tidligere havde siddet en Sølvplade, „der maaske fremstillede Nadverens Indstiftelse“. En tysk Kunsthistoriker, J. Biernatzki, har derimod ment, at Pladen indeholdt en Indskrift i det tyske Sprog. ${ }^{12}$ ) Da Altertavlen er et hamburgsk Arbejde - udført 1662 af Sølvsmeden Hans Lambert III — og da de tilsvarende Sølvaltertavler i Frederiksborg Slotskirke og Storkyrkan i Stockholm, ${ }^{18}$ ) der ogsaa stammer fra hamburgske Værksteder, som Predellabillede har en Fremstilling af Nadverens Indstiftelse, er det sikkert Winstrups Formodning, der er den rigtige. Paa Fodstykket indsatte Winstrup en Sølvplade med en dansk Indskrift. Tanken, at lade et nyt Nadverbillede fremstille, ses ikke at have været fremme. Man kan bebrejde Winstrup, at Indskriften med sine stejle antike Typer falder ud af Værkets Stil, hvorimod Biernatzki's Indvending, at man anvendte dan-

10) Livs- og Krigserindringer p. 143-148.

11) Skriv. fra W. $10 / 51860$.

12) Der Gottorfer Silberaltar, Kunstkalender Schlesw.-Holstein 1918 -19 p. 3 o. fl.

13) Fr. Weilbach: Frederiksborg Slot p. $118 \mathrm{Kbh}$. Gyld. 1923. - Sveriges Kyrkor Bd. I Stockh. 1928 p. 373. 
ske Ord, "Wo doch vorher deutsche standen", er ved Siden af, allerede af den Grund, at der næppe tidligere har staaet nogen tysk Indskrift paa dette Sted.

Ovenover Fodstykket, i nederste Afdeling, er Hovedfeltet, hvor der i Sølvrelief gives en Fremstilling af Korsfæstelsen; her mangler enkelte Ting, som det ene Ben paa en Rytter, nogle Hænder o. s. v., hvilket blev istandsat. Biernatzki mener, at Frelserens Kors er taget ud og erstattet af „et ubehageligt, blankpoleret Kors af Sølvblik"; at dette skulde have fundet Sted, kan ikke ses af de skriftlige Kilder. Paa hver Side af Hovedfeltet er i Tavlens Sidefløje anbragt Nicher til Figurer, "maaske Peter og Paulus". ${ }^{14}$ ) Paa Grund af de store Udgifter veg Winstrup tilbage for at lade to nye Apostle modellere og udføre i Sølv, men agtede i Stedet for at vente indtil man stødte paa passende, ældre Figurer, der kunde anvendes som Model ved Udarbejdelsen af Sølvstatuetterne. Det lykkedes da ogsaa i 1861 Sølvsmed Boysen at finde et Par Apostelfigurer i Hamborg, som han mente kunde anvendes, og paa Grundlag af hvilke han tilbød at fremstille Figurer af Sølv for 90 Rdl. Stykket. ${ }^{13}$ ) Winstrup lovede at se paa dem, naar han atter kom til Slesvig, men der kom intet ud af Sagen. Endnu den Dag i Dag staar Nicherne tomme.

Feltet $i$ anden Afdeling indeholder en Fremstilling af Christi Opstandelse; i sin Indberetning nævner Winstrup det overhovedet ikke; der har dog ogsaa været visse Mangter her, thi 1/2 1861 skriver Sølvsmed Boysen „Pladen med,Opstandelsen.. har jeg i Arbejde“.

Om tredie Afdeling hedder det: „I øverste Afdeling er ligeledes en Plade afbrudt, der maaske fremstiller Christi Himmelfart". Paa dette Sted indsatte man en oval Sølvplade med Fremstilling heraf; af svævende Engle bæres Kristus til Vejrs, han troner allerede og hæver den venstre Haand udover Billedets Rand, parat til at dømme levende og døde. 2 Gange har

14) Skr. 1861 fra W. til Ing. Direktoratet.

15) Skr. 17/4 1861 fra Boysen til W. 
Sølvsmed Boysen ladet sit Navn indgravere i Randen tilligemed Byen Slesvigs Vaaben. De 2 Kunsthistorikere, der har behandlet Altertavlen, Dommer F. Posselt og Biernatzki, gaar ud fra, at man staar overfor et ældre Arbejde og udtaler derfor deres Fordømmelse af, at Boysen har signeret Pladen "grade wie sonst der, der Meisterzeichen gestempelt wird. Das ist also eine offenbare Fälschung, die man kaum für möglich halten sollte ". ${ }^{16}$ ) Sagen er imidlertid ligetil; Pladen er udført af Boysen efter Tegning af Winstrup i Stedet for den manglende. Derimod maa man give Posselt Ret $i$ hans Kritik af, at Pladen blot er paasømmet Træunderlaget, men ikke er forsynet med en Randliste som de andre Plader, og at det ufinerede Træ ses udenom Relieffet.

Den arkitektoniske Opbygning af Altertavlen bæres af svære, drejede Søjler af Ibenholt. Søjleskafterne, Baser, Kapitæler og Lister er prydede med Arbejder i Sølv. I sin Beretning siger Winstrup, at der mangler „alle i Sølv udførte Søjlekapitæler, Sølvforsiringer og nogle Hjørneornamenter". Det manglende blev erstattet, saa vidt muligt paa Grundlag af de foreliggende Brudstykker. I det Winstrupske Arkiv ligger flere af hans Arbejdstegninger til Alteret, saaledes at Restaureringen kan følges i Detailler.

Den Døbefont, der fandtes i Kapellet, var af Støbejærn fra Carlshütten Værkerne ved Rendsborg og var baade uanseelig og uden Samklang med Kirkens Stil. ${ }^{17}$ ) I Stedet for blev der anskaffet en Font, udført hos Stenhugger Klewing i Flensborg efter Winstrups Tegning. Fonten bærer et Daabsfad af fors $ø l-$ vet Kobber, $69 \mathrm{~cm}$ i Diameter. I Bunden af Fadet ses et Relief, forestillende Christi Daab; paa Randen udenom findes billedlige Fremstillinger af Syndefaldet, Syndfloden, Christi Fødsel og Pinsen samt mellem disse de fire Evangelisters Symboler.

16) F. Posselt: Der Silberschatz der Kïrchen, Gilden und Zünften in der Stadt Schleswig, Slesvig 1908. - Posselt p. 24.

$\left.{ }^{17}\right)$ Skr. 23/3 1859 fra W. til Ing. Direktionen. I Høyer Møllers Livsog Krigserindringer p. 117 staar ganske vist: "Døbefont fandtes der ikke i Kirken, far vi toge den i Brug«. 
Fadet er signeret L. Frølich pinx. L. Vieth sculps. 1857 og paa Undersiden staar C. Møller Eneret 1859. ${ }^{18}$ ) Tegningerne til dette Fad havde Frølich oprindelig paabegyndt i Flensborg 1854. Professor H. N. Clausen, der var stærkt interesseret i Opgaven, havde været ham behjælpelig med Emnevalget. Efter mange og lange Forhandlinger udførte omsider den nævnte Billedhugger Vieth Modellen, hvorefter Elektrogalvanisør Caspar Møller-Frølichs og vistnok ogsaa Winstrups gode Ven fra Rom - lod Fadene fremstille ad galvanisk Vej i Kobber; sandsynligvis er de dog ogsaa blevet eftercicelerede. Disse Fade, der solgtes for 230 Rdl. Stykket, findes i forskellige sjællandske Kirker. $\left.{ }^{10}\right)$ Fadet til Gottorp havde kostet 250 Rdl., da det som nævnt var forsølvet; man ser ofte anført, at det var en Gave fra danske Officerer..$^{20}$ ) Dette er urigtigt. Anskaffelsen er ganske simpelt includeret $\mathrm{i}$ det samlede Budget til Kirkens Restaurering.

Den nye Døbefont blev henstillet mellem de to sidste Søjler i Søjlerækken i venstre Sideskib, og her indrettede Winstrup et lille Daabskapel, idet Bagvæggen, som var bar, blev beklædt med Panel; en Dør førte ind til et indemuret Skab til Opbevaring af Kirkens hellige Kar. Mellem Søjlerne, altsaa ud mod Kirkerummet, anbragtes en halvlukket Skranke, som blev baaret af Messingbalustre fra det tidligere Korgitter.

Forvandlingen fra Slotskapel til Kirke for den danske Menighed var fuldbyrdet. Vel kan der rettes Indvendinger mod Winstrups Restaurering, men det maa aldrig glemmes, at han reddede Kapellet fra Forfald og skabte en Ramme om det Menighedsliv, der nu skulde udfolde sig. „Min lille velsignede

18) A. Holst Jorgensen i »Thyras Vold« 15/7 43 p. 273.

19) Lorenz Frølich: Egne Optegnelser og Breve til og fra hans Slæagt og Venner. Samlet og udgivet af F. Henriksen 1920, p. 253, 260, 262, 276 og 283.

20) F. Eks. H. V. Clausens Rejsehaandbog Sønderjylland 1932 p. 194. Høyer Møller skriver: Fadet havde kostet $500 \mathrm{Kr}$. og blev, saavidt jeg husker det, skænket af $H$. M. Kongen - Livs- og Krigserindringer p. 118. 
Kirke“ skriver Høyer Møller, ${ }^{21}$ ) „hvor var du mig kær og blev det mere Dag for Dag! Hvor det pinte mig, at jeg maatte forlade dig. Endnu efter saa mange Aars Forløb tænker jeg paa dig med samme Følelse som Israel, da det sad ved Babylons Floder".

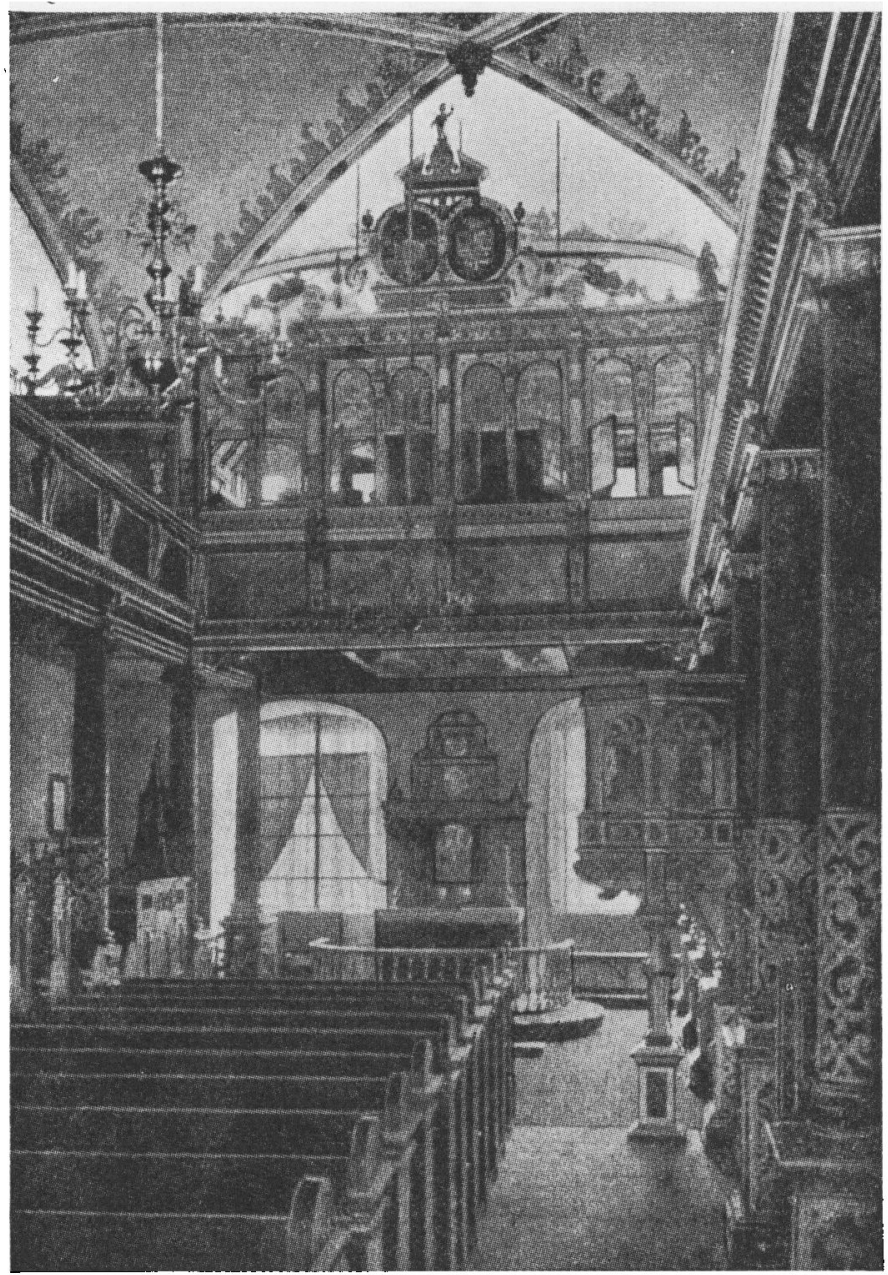

Afb. 24. Slotskapelle! paa Gottorp, set mod Alteret og Fyrstestolen.

21) Livs- og Krigserindringer p. 116. 